\title{
molecules
}

ISSN 1420-3049

(C) 2007 by MDPI

www.mdpi.org/molecules

Review

\section{Synthetic Approaches to Heterocyclic Ligands for Gd-Based MRI Contrast Agents}

Elena Pérez-Mayoral ${ }^{1,2}$, Jordi Soler-Padrós ${ }^{1}$, Viviana Negri ${ }^{1}$, Sebastián Cerdán ${ }^{3}$ and Paloma Ballesteros ${ }^{1, *}$

${ }^{1}$ Laboratorio de Síntesis Orgánica e Imagen Molecular por Resonancia Magnética, Facultad de Ciencias, UNED, Paseo Senda del Rey 9, E-28040 Madrid, Spain

2 Departamento de Química Inorgánica y Química Técnica, Facultad de Ciencias, UNED, Paseo Senda del Rey 9, E-28040 Madrid, Spain

${ }^{3}$ Laboratorio de Imagen Espectroscópica por Resonancia Magnética (LIERM), Instituto de Investigaciones Biomédicas “Alberto Sols”, CSIC/UAM, C/ Arturo Duperier 4, E-28029 Madrid, Spain

* Author to whom correspondence should be addressed; E-mail: pballesteros@ccia.uned.es. Phone: (+34) 913987320. Fax: (+34) 913986697.

Received: 29 May 2007; in revised form: 3 August 2007/ Accepted: 3 August 2007 / Published: 9 August 2007

Abstract: Magnetic Resonance Imaging (MRI) methods are currently used in the clinic for the non invasive detection and characterization of a wide variety of pathologies. Increases in the diagnostic efficiency of MRI have been helped by both the design of dedicated MR sequences revealing specific aspects of the pathology and by the development of more sensitive and selective Contrast Agents (CAs), capable of more precisely delineating the borderline regions. In the present review we focus on the synthetic strategies used to obtain MRI CAs containing heterocyclic rings.

Keywords: Lanthanide Complexes, Contrast Agents, Heterocyclic Ligands, MR Imaging 


\section{Contents}

1. Introduction

1772

2. Contrast Agents (CAs) for MRI: Gd-based complexes

2.1. CAs derived from acyclic ligands

1774

2.2. CAs derived from macrocyclic ligands

1784

3. Concluding remarks and future perspectives

1790

\section{Introduction}

Cardiovascular and neurodegenerative diseases, as well as tumors, are often clinically diagnosed using non invasive methods such as PET (Positron Emission Tomography) [1,2], SPECT (Single Photon Emission Tomography) [2], MRI (Magnetic Resonance Imaging) [3], Optical Imaging [4], ultrasound methods [5] or their multimodal combinations [6]. In many cases all of these methods involve the additional use of specific probes (known as Contrast Agents, CAs) to increase image resolution and discrimination between healthy and pathological areas. Therefore, the development of more sensitive, selective and efficient CAs is an important task of strategic interest due to their potential applications in many biomedical imaging procedures. Classically the widespread presence of heterocyclic rings in Nature and their very favorable coordinating properties have prompted the use of a variety of nitrogen-based heterocycles in the manufacture of many CAs. As a more recent example, Fu et al. [7] have described a new family of benzoylpiperidines 1 (Figure 1) as serotonin 5-HT $\mathrm{H}_{2 \mathrm{~A}}$ ligands for PET or SPECT Imaging of the brain. Notably, in spite of the considerable progress of MRI and PET protocols, X-Ray Imaging still accounts for $75-80 \%$ of all diagnostic imaging procedures. In this respect, non-ionic X-Ray CAs based on the attachment of heterocyclic moieties to the 5-position of diatrizoic acid (2) or iohexol (3) have been reported [8]. Most of these new X-Ray contrast agents consist of sterically congested lactams 4, derived from the 2,4,6-triiodoisophthalamide, which exhibit water solubility, stability and osmolality, depending on the heterocycle included. Approaches based on optical methods are fast emerging as alternatives to conventional X-Ray Imaging. Near Infra-Red light (NIR) is increasingly being considered nowadays as a powerful non-invasive biomedical imaging tool. It is specially recommended as a complementary method to X-ray mammography for examinations of young women with dense breast tissues or patients with scars and implants, often employing NIR absorbing dyes. Indocyanine green (ICG, 5) is a clinically approved NIR dye used for testing of hepatic function and fluorescence angiography in ophthalmology and even for detection of breast tumors [9]. NIR dye 6, a modification of ICG, overcomes many of its limitations with regards to spatial resolution and sensitivity [10].

In the following sections we address the various synthetic strategies developed to produce heterocyclic ligands useful for preparing Gadolinium based CAs for MRI [11]. The present work complements these contributions by addressing in more detail the heterocyclic chemistry involved in these processes. 
Figure 1. Some useful probes for PET, SPECT, X-Ray and Optical Imaging.

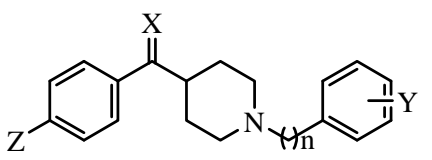

1

$\mathrm{n}=1,2$

$\mathrm{X}=\mathrm{H}, \mathrm{O}, \mathrm{OH}$

$\mathrm{Y}=\mathrm{H}, 2-\mathrm{I}, 3-\mathrm{I}, 4-\mathrm{I}, 4-\mathrm{F}$

$\mathrm{Z}=\mathrm{F}, \mathrm{NO}_{2}$

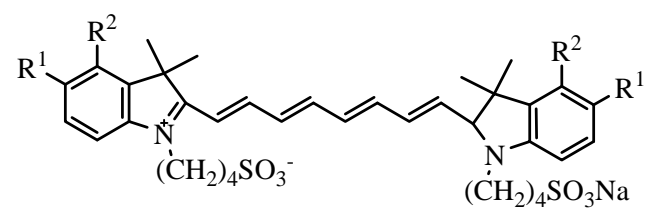<smiles>[R]C(=O)c1c(I)c(C([R])=O)c(I)c(C([R])=O)c1I</smiles>

2: $\mathrm{R}^{1}=\mathrm{OH} ; \mathrm{R}^{2}=\mathrm{R}^{3}=\mathrm{NHCOCH}_{3}$ 3: $\mathrm{R}^{1}=\mathrm{R}^{2}=\mathrm{NH}-\mathrm{CH}_{2} \mathrm{CH}(\mathrm{OH}) \mathrm{CH}_{2} \mathrm{OH}$

$\mathrm{R}^{3}=\mathrm{N}\left(\mathrm{COCH}_{3}\right) \mathrm{CH}_{2} \mathrm{CH}(\mathrm{OH}) \mathrm{CH}_{2} \mathrm{OH}$ $4: \mathrm{R}^{1}=\mathrm{R}^{2}=\mathrm{NH}-\mathrm{CH}_{2} \mathrm{CH}(\mathrm{OH}) \mathrm{CH}_{2} \mathrm{OH}$

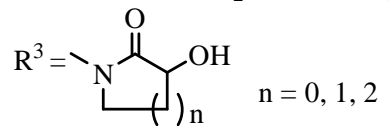

5: $\mathrm{R}^{1}$ and $\mathrm{R}^{2}=\mathrm{CH}=\mathrm{CH}-\mathrm{CH}=\mathrm{CH}$

6: $\mathrm{R}^{1}=\mathrm{CO}$-glucamide; $\mathrm{R}^{2}=\mathrm{H}$

Glucamide $={ }_{\mathrm{H}}^{-} \overbrace{\mathrm{HO}}^{\mathrm{OH}} \underbrace{\mathrm{OH}}_{\mathrm{H}}$

\section{Contrast Agents (CAs) for MRI: Gd-based complexes}

As mentioned above, the diagnostic efficiency by many MRI methods frequently relies on the use of a new type of drugs, referred to as contrast agents (CAs), able to discriminate between normal and pathological tissues due to their different MR properties [11-13]. The role of the CAs is to enhance the MRI signal by shortening the relaxation times of water protons in those tissues in which they distribute. Generally, the most investigated paramagnetic CAs are lanthanide complexes, with particular emphasis on the corresponding $\mathrm{Gd}(\mathrm{III})$-chelates. $\mathrm{Mn}$ (II) and $\mathrm{Fe}(\mathrm{III})$ salts have also been investigated as paramagnetic metals, but they often become weakly chelated and dissociate spontaneously under in vivo conditions [14].

As mentioned, the paramagnetic metal of choice in clinical practice is generally $\mathrm{Gd}(\mathrm{III})$, but free $\mathrm{Gd}(\mathrm{III})$ is toxic in vitro as well as in vivo, and the use of $\mathrm{Gd}(\mathrm{III})$ chelates becomes mandatory in biomedical applications to reduce its toxicity. Gd(III) remains the optimal paramagnetic ion because of its high electronic spin ( $S=7 / 2)$, relatively long electronic relaxation time, high magnetic moment and relatively labile hydration sphere for water exchange. The first generation of Gd(III) chelates was derived from linear or macrocyclic polyaminopolycarboxylates such as diethylenetriaminepentaacetic acid ([dtpaGd $\left.\left(\mathrm{H}_{2} \mathrm{O}\right)\right]^{2-}$ ) or 1,4,7,10-tetraazacyclododecane-1,4,7,10-tetraacetic acid ([dotaGd $\left.\left.\left(\mathrm{H}_{2} \mathrm{O}\right)\right]^{-}\right)$, respectively (Figure 2) [11]. Gd-Dtpa, patented as Magnevist ${ }^{\circledR}$ by Schering (Germany), was the first CA approved for clinical use. Gd-Dota (Dotarem ${ }^{\circledR}$, Guerbet, France), Gd-Dtpa-BMA (Omniscan ${ }^{\circledR}$, Amersham, Great Britain), Gd-HP-DO3A (Prohance ${ }^{\circledR}$, Bracco, Italy), Gd-Dtpa-BMEA (Optimark ${ }^{\circledR}$, Mallinkrodt, USA) and Gd- DO3A-Butriol (Gadovist ${ }^{\circledR}$, Schering, Germany) followed as other Gdbased CAs commonly used in clinical practice. All of them present similar pharmacokinetic properties and renal elimination rates.

The modification of both linear and macrocyclic parental structures, Gd-Dtpa and Gd-Dota, is currently found to be an essential part of the investigations generating new CAs with improved magnetic properties. In this respect, new Gd-based CAs must exhibit sufficiently high thermodynamic 
and kinetic stabilities as important determinants for their use in MRI diagnosis. In addition, the CA's must have improved molecular relaxivity properties, $r_{1}$ or $r_{2}\left(s^{-1} \mathrm{mM}^{-1}\right)$, defined as the longitudinal or transversal relaxation rates of the water protons in a $1 \mathrm{mM}$ aqueous solution of the $\mathrm{Gd}(\mathrm{III})$-chelate.

Figure 2. Gd(III) complexes commonly used in clinical practice.<smiles>O=C(O)CN(CCN(CC(=O)O)CC(=O)O)CCN(CC(=O)O)CC(=O)O</smiles>

Gd-DTPA (Magnevist $\left.{ }^{\circledR}\right)$<smiles>O=C(O)CN1CCN(CC(=O)O)CCN(CC(=O)O)CCN(CC(=O)O)CC1</smiles>

Gd-DOTA (Dotarem $\left.{ }^{\circledR}\right)$<smiles>CNC(=O)CN(CCN(CCO)CC(=O)O)CC(=O)O</smiles>

Gd-DTPA-BMA (Omniscan®)<smiles>CC(O)CN1CCN(CC(=O)O)CCN(CC(=O)O)CCN(CC(=O)O)CC1</smiles>

Gd-HP-DO3A (Prohance $\left.{ }^{\circledR}\right)$<smiles>CCN(CCN(CCO)CCN(CC(=O)O)CC(=O)NCCOC)CC(=O)O</smiles>

Gd-DTPA-BMEA (Optimark $\left.{ }^{\circledR}\right)$

DO3A-Butriol (Gadovist ${ }^{\circledR}$ )

The following sections cover the synthetic approaches used to prepare these ligands, emphasizing the synthetic methodologies implemented to obtain heterocyclic chelators resulting progressively in more stable Gd complexes.

\subsection{CAs derived from acyclic ligands}

Miyake et al. [15] have reported a new type of optically active acyclic ligands $\mathbf{7}$ and $\mathbf{8}$ derived from $(S)$-aspartic acid and (S)-histidine (Scheme 1). Their Gd(III)-complexes exhibited a high relaxivity ( $\mathrm{r}_{1}$ = 9.4 and $9.9 \mathrm{~s}^{-1} \mathrm{mM}^{-1}$, respectively, at $300 \mathrm{MHz}$ and $295 \mathrm{~K}$ ), but their thermodynamic stability was not sufficient to be clinically relevant. Inclusion of pyridine ring was carried out by reductive amination between the corresponding amino acid and pyridine 2-carbaldehyde, affording compounds 9 and 10. Reaction of 9 with 2,2-dimethoxyacetaldehyde in the presence of $\mathrm{NaBH}_{3} \mathrm{CN}$, followed by treatment in acidic medium yielded compound 11, which by condensation with $\mathbf{9}$ or $\mathbf{1 0}$ under the mentioned conditions and subsequent basic hydrolysis, afforded the chelating ligands $\mathbf{7}$ and $\mathbf{8}$.

Pyridine derivatives 12a-c, also based on ethylendiamine backbone, were recently reported by Platas-Iglesias et al. (Scheme 2) [16]. Compounds 12a-c were synthesized from 2,6-pyridinedicarboxylic acid dimethyl ester by reduction of one of the ester groups using $\mathrm{NaBH}_{4}$ in $\mathrm{MeOH}$, followed by oxidation of the corresponding alcohol yielding compound 13. Condensation of 13 with ethylendiamine and subsequent reduction of the imine derivative gave compounds 14a-b. Alkylation of 14a with tert-butyl bromoacetate and deprotection of the ester moieties in acidic medium afforded 12a. Compound 12b was synthesized from precursor 14b by Mannich-type reaction with paraformaldehyde and phosphorous acid in $6 \mathrm{M} \mathrm{HCl}$ [17]. Finally, chelate 12c, containing the same structural skeleton with the ethyl bridge substituted by a more rigid cyclohexyl moiety, was prepared using the same synthetic sequence used to prepare 12b (Scheme 2) [18]. Gd-12a induced an $\mathrm{r}_{1}$ value $5.0 \mathrm{~s}^{-1} \mathrm{mM}^{-1}$ measured at $20 \mathrm{MHz}$ and $25^{\circ} \mathrm{C}$. 
Scheme 1. Optically active acyclic ligands derived from (S)-aspartic acid and (S)-histidine.

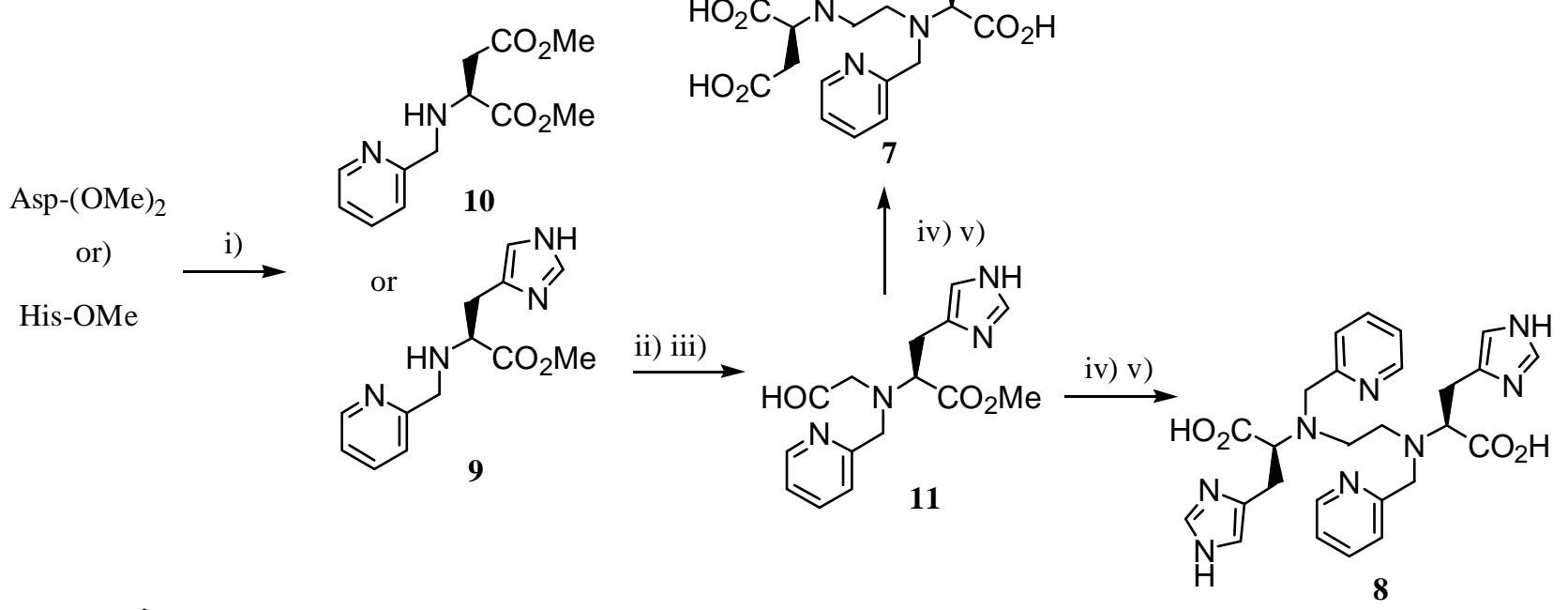

i) $\overbrace{\mathrm{N}}^{-2}, \mathrm{NaBH}_{3} \mathrm{CN}$; ii) $(\mathrm{MeO})_{2} \mathrm{CHCHO}, \mathrm{NaBH}_{3} \mathrm{CN}$; iii) $\mathrm{HBr}, \mathrm{AcOH}$; iv) 9 or $\mathbf{1 0}, \mathrm{NaBH}_{3} \mathrm{CN}$; v) $\mathrm{OH}^{-}$

Scheme 2. Pyridine derivatives 12a-c based on an ethylendiamine chelate.

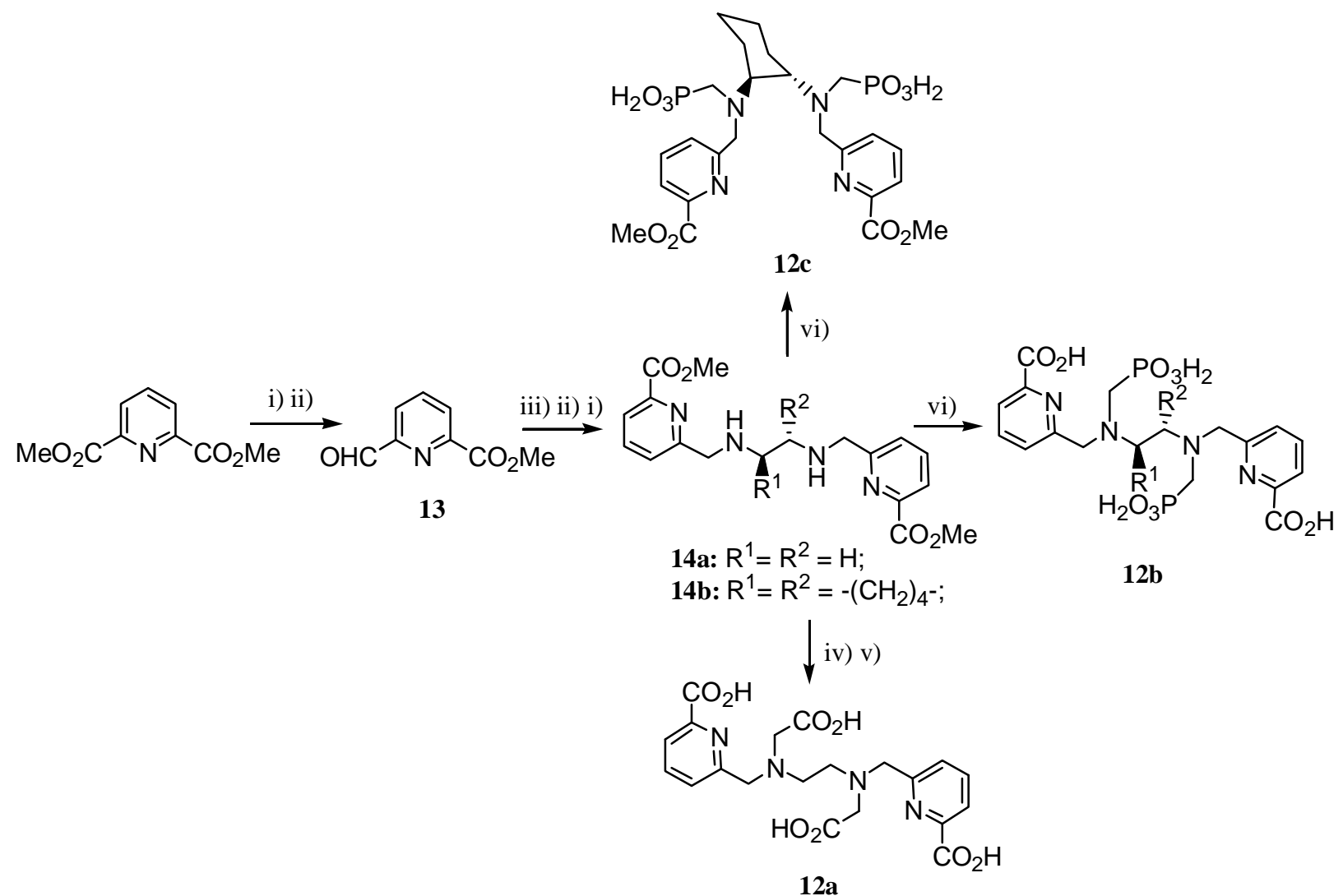

i) $\mathrm{NaBH}_{4}, \mathrm{MeOH}$; ii) $\mathrm{SeO}_{2}$, dioxane; iii) ethylendiamine or 1,2-cyclohexyldiamine, $\mathrm{MeOH}$; iv) tert-butyl bromoacetate, $\mathrm{Na}_{2} \mathrm{CO}_{3}$, acetonitrile; v) $\mathrm{HCl}$; vi) paraformaldehyde, phosphorous acid, $\mathrm{HCl}(6 \mathrm{M})$

López et al. [19] have reported the synthesis of a novel series of chelating ligands 15 containing nitrogen heterocycles, such as pyrazole and indazole, which form tetradentate complexes with Gd(III). 
These Gd(III)-complexes were considered as $\mathrm{T}_{2}$ relaxation agents for MRI $\left(\mathrm{r}_{1}\right.$ 4.6-5.9 $\mathrm{s}^{-1} \mathrm{mM}^{-1} ; \mathrm{r}_{2}$ 7.4$13.9 \mathrm{~s}^{-1} \mathrm{mM}^{-1}$ at $360 \mathrm{MHz}$ and $25^{\circ} \mathrm{C}$ ). Their synthesis was carried out starting from the corresponding heterocyclic rings by alkylation, using phase transfer conditions, to give compounds $\mathbf{1 6}$. Reaction of 16 with methyl iminodiacetate and subsequent acid or basic hydrolysis of the corresponding methyl ester afforded the chelating ligands $\mathbf{1 5}$ (Scheme 3).

\section{Scheme 3.}

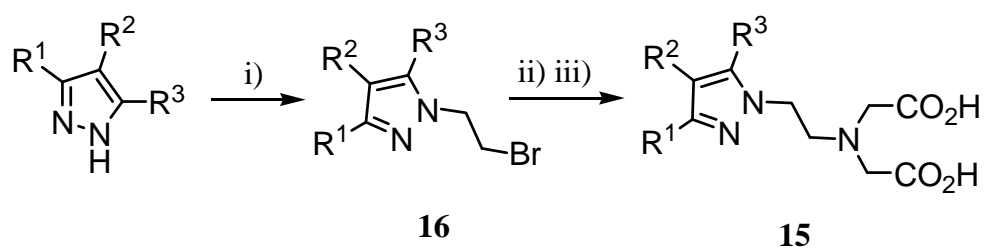

$$
\begin{aligned}
\text { a: } \mathrm{R}^{1} & =\mathrm{R}^{2}=\mathrm{R}^{3}=\mathrm{H} \\
\text { b: } \mathrm{R}^{1} & =\mathrm{R}^{3}=\mathrm{Me} ; \mathrm{R}^{2}=\mathrm{H} \\
\text { c: } \mathrm{R}^{1}=\mathrm{H} ; & \\
\mathrm{R}^{2} & =\mathrm{R}^{3}=-\mathrm{CH}=\mathrm{CH}-\mathrm{CH}=\mathrm{CH} \\
\text { d: } \mathrm{R}^{3} & =\mathrm{H} ; \\
\mathrm{R}^{1} & =\mathrm{R}^{2}=-\mathrm{CH}=\mathrm{CH}-\mathrm{CH}=\mathrm{CH}
\end{aligned}
$$

i) 1,2-dibromoethane, $\mathrm{NaOH}, \mathrm{TBAB}$; ii) methyl iminodiacetate, $120^{\circ} \mathrm{C}$; iii) $\mathrm{NaOH}$ or $\mathrm{HCl}$

In a similar fashion, Mayoral et al. [20] described a novel family of chelating agents $\mathbf{1 7}$ containing bi- and bis-pyrazole structure, which form double tetradentate complexes with Gd(III). They exhibited a larger relaxivity in a range of $13.8-37.0 \mathrm{~s}^{-1} \mathrm{mM}^{-1}\left(60 \mathrm{MHz}\right.$ and $\left.37^{\circ} \mathrm{C}\right)$, even compared to dendrimers with numerous metallic centers (Figure 3). Ligands 17a-d were obtained by alkylation of the corresponding bi or bispyrazole, reaction with methyl iminodiacetate and followed by the basic hydrolysis as mentioned above for the preparation of $\mathbf{1 5}$ (Scheme 3).

Figure 3. Chelating ligands for Gd(III) with Bi and bis-pyrazole skeleton.

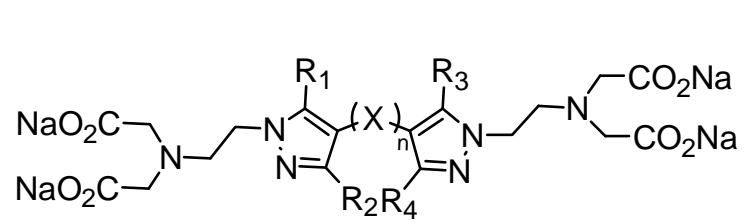

17

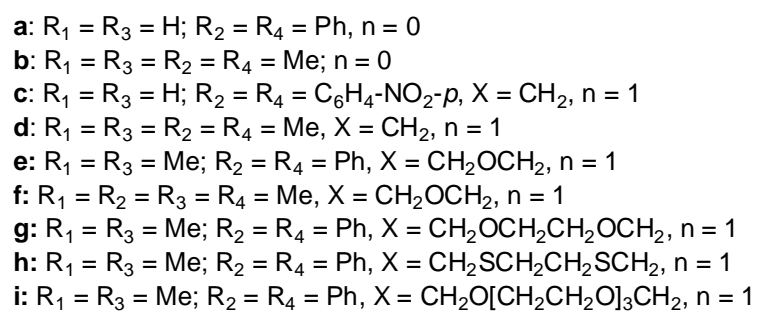

Chelators 17e-i were synthesized from the chloromethyl pyrazoles 18 prepared by condensation of the appropriate pyrazole with paraformaldehyde (Scheme 4) [21].

Scheme 4. Gd(III) Chelators from 4-chloromethylpyrazoles.

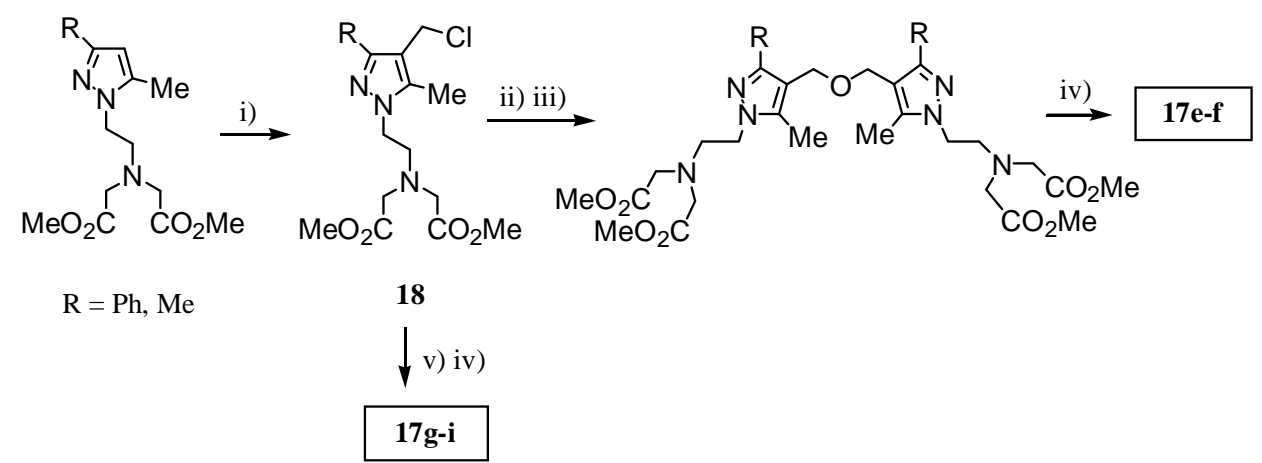

i) paraformaldehyde, $\mathrm{ClH}_{(\mathrm{g})}$; ii) $\mathrm{H}_{2} \mathrm{O}$; iii) $\mathrm{CF}_{3} \mathrm{CO}_{2} \mathrm{H}, \mathrm{CH}_{2} \mathrm{Cl}_{2}$ (only for synthesis of $\mathbf{1 7 f}$ ); iv) $\mathrm{NaOH}(0.6 \%$ in water); v) NuH, DMF ( $\left.\mathrm{NuH}=\mathrm{H}_{2} \mathrm{O}, \mathrm{HO}\left[\mathrm{CH}_{2} \mathrm{CH}_{2} \mathrm{O}\right]_{n} \mathrm{H}(\mathrm{n}=1,3), \mathrm{HSCH}_{2} \mathrm{CH}_{2} \mathrm{SH}\right)$ 
Compounds 18 were extremely reactive species, reacting with the corresponding nucleophiles to give different products, depending on the starting substrate. When compounds $\mathbf{1 8}$ reacted with water, complexones 17e-f were isolated after basic hydrolysis of the corresponding ester, while compounds $\mathbf{1 7 g - i}$ were prepared by reaction of $\mathbf{1 8}$ with the nucleophile shown in Scheme 4.

Heptadentate ligand 19 containing three pyridine rings was synthesized in two steps according to Scheme 5. Alkylation of $\mathbf{2 1}$ with the pyridylmethyl chloride $\mathbf{2 0}$ lead to compound 22, which when treated with $\mathrm{NaOH} / \mathrm{EtOH}$ afforded the ligand 19. Gd(III)-19 showed an unusual and higher relaxivity with respect to the other heptadentate complexes $\left(13.3 \mathrm{~s}^{-1} \mathrm{mM}^{-1}\right.$ measured at $60 \mathrm{MHz}$ and $\left.298 \mathrm{~K}\right)$ [22].

Scheme 5.

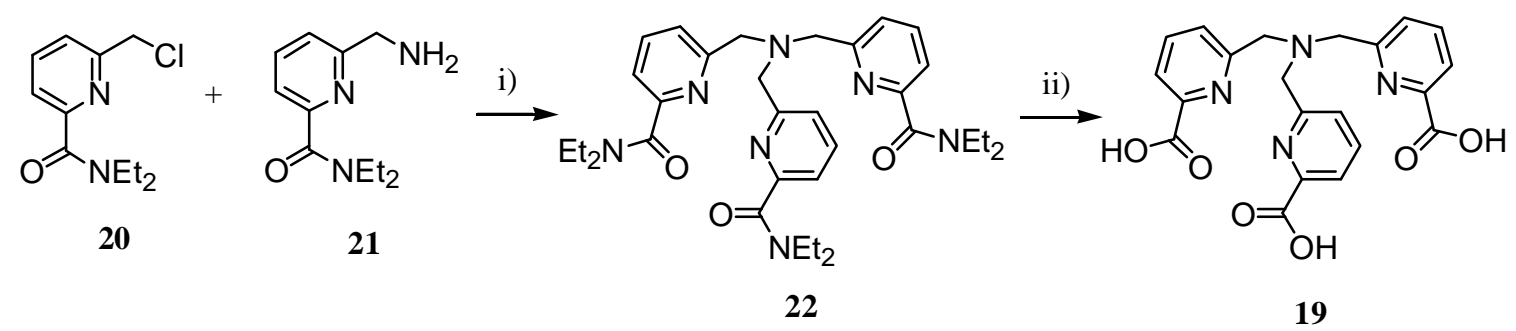

i) $\mathrm{K}_{2} \mathrm{CO}_{3}$, acetonitrile, reflux; ii) $\mathrm{NaOH}$, EtOH

The Gd(III)-complex of ligand $\mathbf{2 3}$ with a pyridine ring as part of the triamine skeleton was reported by Aime et al. [23]. This complex showed a high relaxivity $\left(9.1 \mathrm{~s}^{-1} \mathrm{mM}^{-1}\right.$ at $20 \mathrm{MHz}$ and $\left.25{ }^{\circ} \mathrm{C}\right)$ in comparison with other heptacoordinating complexes, probably due to the presence of the hydroxyl groups that contribute to an increase of the second coordination sphere of the complex. Compound 23 was synthesized in two steps through a double-Mannich reaction, as shown in Scheme 6. Thus, reaction of 3,5-dyhydroxypyridine with paraformaldehyde and ethyl iminodiacetate gave compound 24, whose treatment with 6M ClH afforded 23 in good overall yield (56\%).

\section{Scheme 6.}
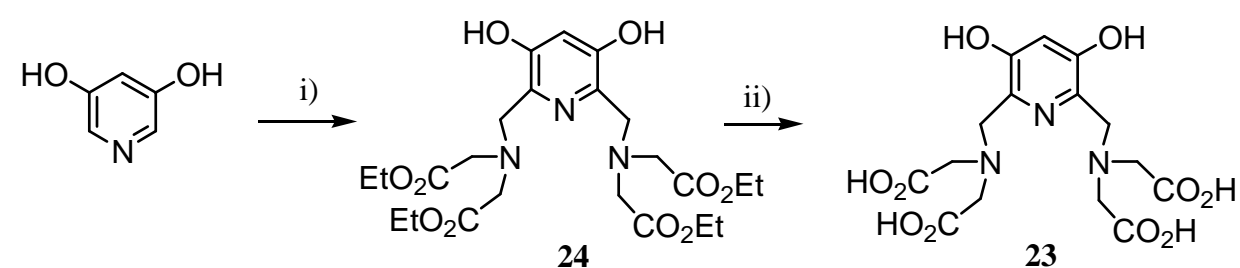

i) $\left(\mathrm{CH}_{2} \mathrm{O}\right)$ n, ethyl iminodiacetate, EtOH, reflux; ii) $6 \mathrm{M} \mathrm{HCl}$ reflux

High stability constants and high relaxivity values are the essential requirements of a Gd-complex to be a potential CA for MRI. Consequently, design of octadentate chelating ligands is pursued in most investigations of new CAs with high stability constants. Dtpa analogues derived from piperidine and azepane 25 and $\mathbf{2 6}$ have been reported as potential CAs for MRI [24]. The synthetic routes used to prepare them firstly involved the functionalised heterocycles synthesis and subsequent alkylation (Scheme 7). The synthesis of $\mathbf{2 5}$ and $\mathbf{2 6}$ started from the piperidine 27, which after benzylation of amine group and subsequent ester reduction afforded the compound $\mathbf{2 8 .}$ 
Scheme 7. Dtpa analogues derived from piperidine and azepane.

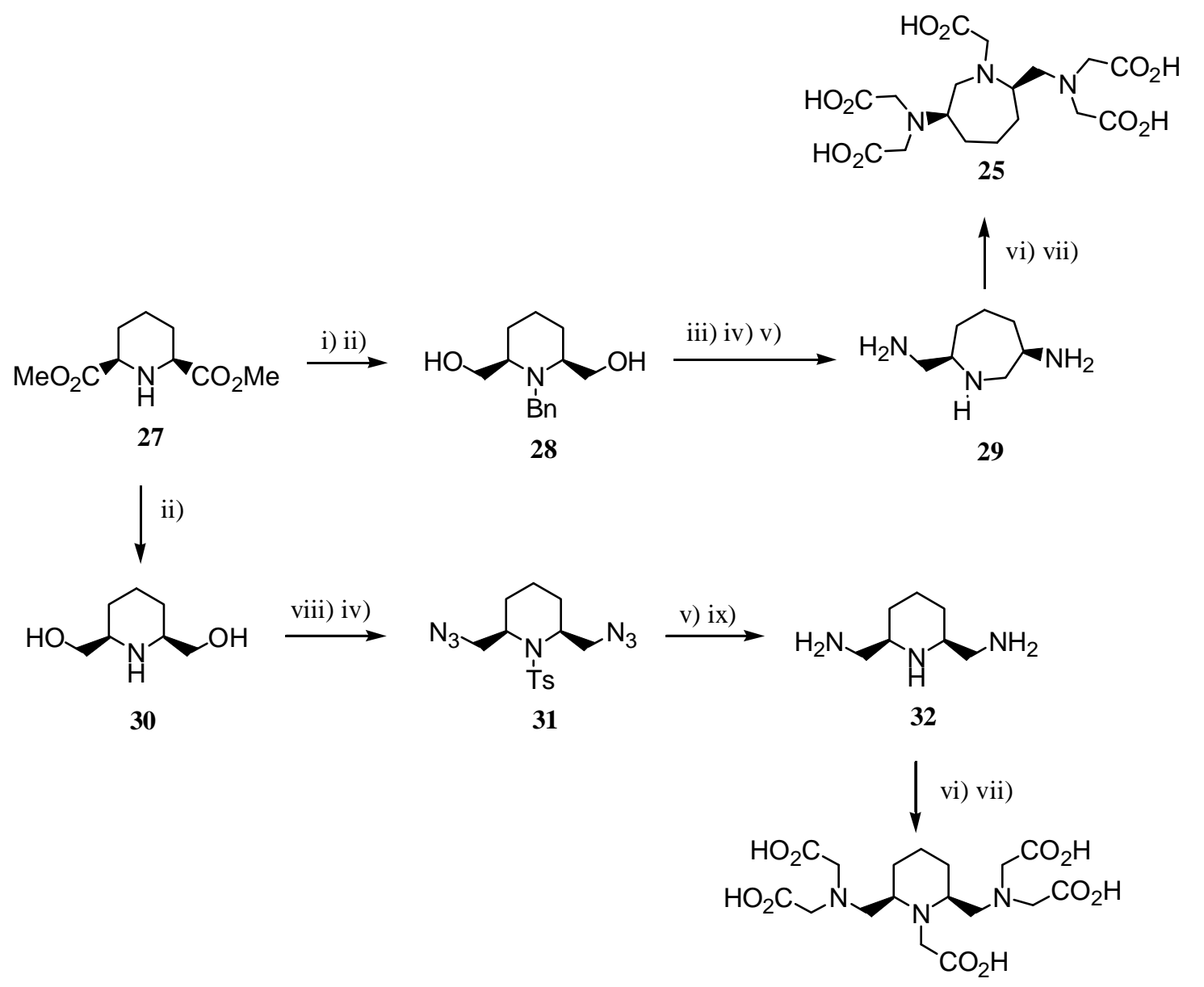

26

i) $\mathrm{Bn}-\mathrm{Br}, \mathrm{K}_{2} \mathrm{CO}_{3}$, acetonitrile, reflux; ii) $\mathrm{LiBH}_{4}$, THF; iii) $\mathrm{SOCl}_{2}$, benzene, $60{ }^{\circ} \mathrm{C}$; iv) $\mathrm{NaN}_{3}$, DMSO, $90{ }^{\circ} \mathrm{C}$;

v) $\mathrm{H}_{2}$, $\mathrm{Pd} / \mathrm{C} \mathrm{R-OH}$; vi) tert-butyl bromoacetate, acetonitrile; vii) $\mathrm{HCl}_{(\text {g) }}$ dioxane; viii) $\mathrm{TsCl}$, $\mathrm{Et}_{3} \mathrm{~N}, \mathrm{CH}_{2} \mathrm{Cl}_{2}$;

ix) $\mathrm{H}_{2} \mathrm{SO}_{4}, 115^{\circ} \mathrm{C}$

Treatment of $\mathbf{2 8}$ with thionyl chloride followed by reaction with sodium azide induces the ring expansion giving the corresponding azide, which was reduced to give the diamine 29. On the other hand, reduction of 27 using $\mathrm{LiBH}_{4}$ lead to compound 30, which by reaction with p-toluensulfonyl chloride followed by treatment with sodium azide gave compound 31. Reduction of the azide groups in compound 31 and subsequent treatment with concentrated $\mathrm{H}_{2} \mathrm{SO}_{4}$ afforded diamine 32. Finally, alkylation of $\mathbf{2 9}$ and $\mathbf{3 2}$ using tert-butyl bromoacetate and subsequent treatment with an acidic medium lead to $\mathbf{2 5}$ and 26, respectively.

In the same way, Cheng T.-H. et al. [25] reported the Gd(III)-complex of $N^{\prime}$-2-pyridylmethyl derivative 33 showing similar relaxivity values $\left(4.2 \mathrm{~s}^{-1} \mathrm{mM}^{-1}\right.$ at $20 \mathrm{MHz}$ and $310 \mathrm{~K}$ ) and stability constants to Gd(III)-dtpa. This ligand was synthesized from diethylenetriamine with protection of the terminal amine groups according to the route shown in Scheme 8. Alkylation of the central nitrogen of the amine backbone gave compound $\mathbf{3 4}$, which was sequentially treated with acid, alkylated with tertbutyl bromoacetate and finally hydrolysed in acidic medium yielding ligand 33. 
Scheme 8.

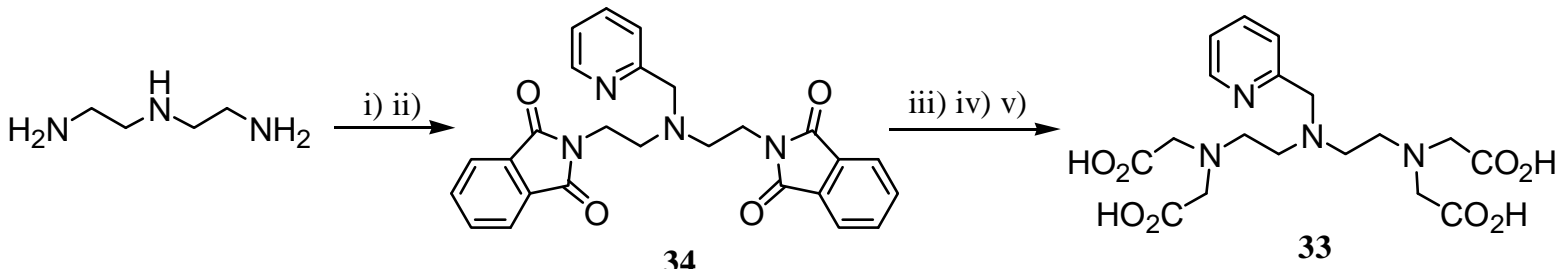

34

i) Phathalic anhydride, $\mathrm{MeOH}$; ii) 2-picolyl chloride, $\mathrm{NaOH}$; iii) $\mathrm{HCl}$, reflux; iv) tert-butyl bromoacetate, $\mathrm{K}_{2} \mathrm{CO}_{3}$, acetonitrile; iv) $\mathrm{HCl}$, rt

Recently, we reported an experimental and theoretical study of lanthanide complexes of the modified dtpa derivative 35 that includes a 3,5-dimethylpyrazolylethyl arm, corroborating the effective azole coordination with the metal center [26]. This compound was synthesized starting from $N, N^{\prime}-$ Boc-diethylenetriamine using a similar synthetic approach as for 33, which gave $\mathbf{3 5}$ in $\mathbf{8 3 \%}$ overall chemical yield (Scheme 9). The corresponding Gd-complex of 35 exhibited an $\mathrm{r}_{1}$ value of $5.1 \mathrm{~s}^{-1} \mathrm{mM}^{-1}$ measured at $60 \mathrm{MHz}$ and $310 \mathrm{~K}$.

\section{Scheme 9.}

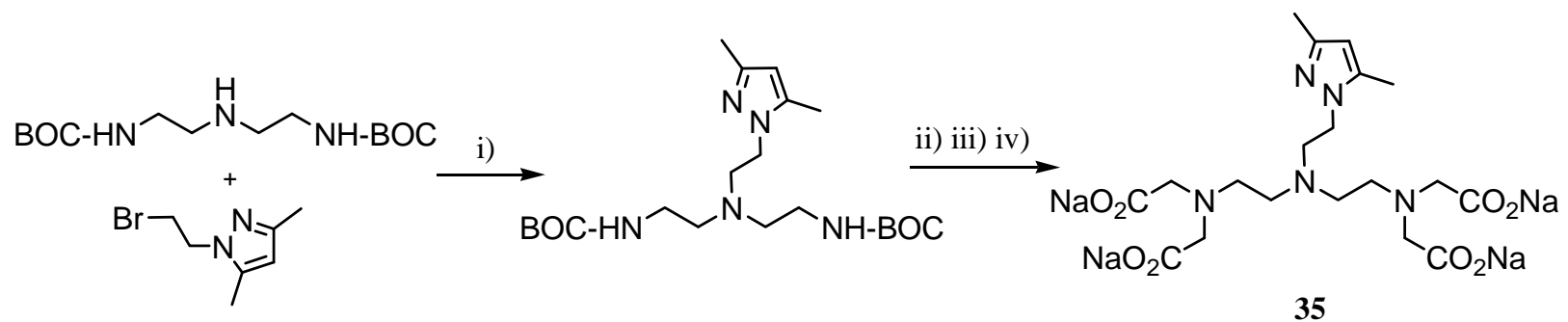

i) $\mathrm{Na}_{2} \mathrm{CO}_{3}$, acetonitrile; ii) $\mathrm{HCl} / \mathrm{MeOH}(6 \mathrm{~N})$; iii) methyl bromoacetate, $\mathrm{Na}_{2} \mathrm{CO}_{3}$, acetonitrile; iv) $\mathrm{NaOH}$

Relaxivity properties of Gd-based CAs can be increased restricting the motion of the complexes by linking to macromolecules through covalent or non-covalent bonds [11,12b]. This approach was used by Ruloff et al. [27] to prepare the complex [Fe $\left\{\mathrm{Gd} \mathrm{36}\left(\mathrm{H}_{2} \mathrm{O}\right)_{2}\right\}_{3}$ ] from ligand 36, obtained by a similar synthetic pathway as mentioned for compound 35 (Scheme 9 and Figure 4). The $\mathrm{r}_{1}$ for this complex was $22.9 \mathrm{~s}^{-1} \mathrm{mM}^{-1}(60 \mathrm{MHz}, 298 \mathrm{~K})$.

\section{Figure 4.}

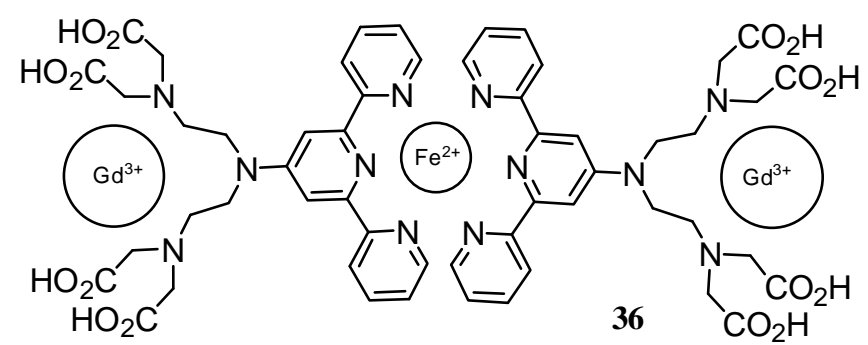

On the other hand, a heterometallic self-assembled metallostar was prepared from ligand 37 synthesized using the same route mentioned above (Scheme 10) [28]. The multinuclear complex $\left[\mathrm{Fe}\left\{\mathrm{Gd}_{2} 37\left(\mathrm{H}_{2} \mathrm{O}\right)_{4}\right\}_{3}\right]^{4-}$ is a rigid supramolecular structure containing two water molecules per Gd(III) 
ion in the inner-sphere. Its high relaxivity $\left(27 \mathrm{~s}^{-1} \mathrm{mM}^{-1}\right.$ at $20 \mathrm{MHz}$ and $25^{\circ} \mathrm{C}$ ) is comparable to a Gd(III)-Dota-loaded generation 10 dendrimer.

\section{Scheme 10.}

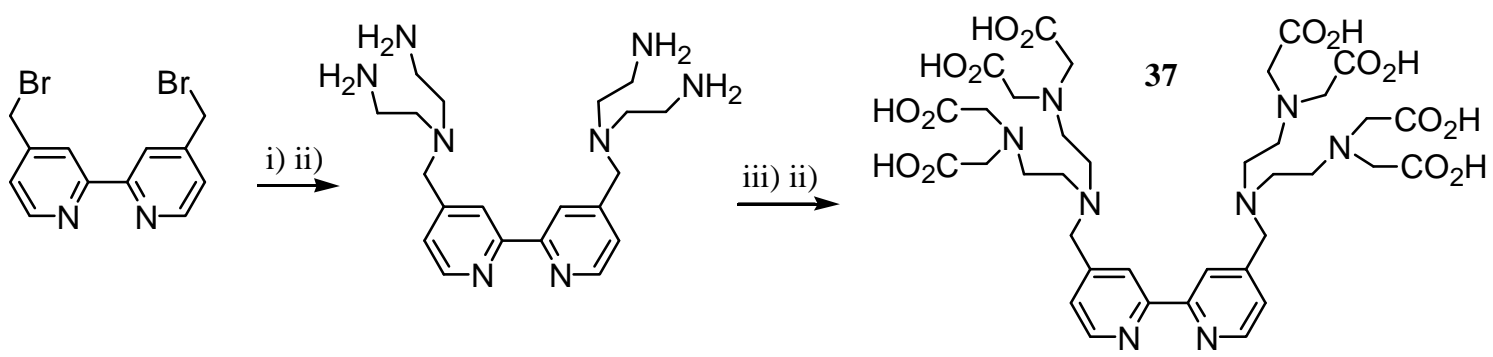

i) protected triamine, $\mathrm{K}_{2} \mathrm{CO}_{3}$, acetonitrile; ii) $6 \mathrm{M} \mathrm{ClH}$; iii) tert-butyl bromoacetate, DIEA, KI, DMF

Parac-Vogt et al. [29] reported a stable dinuclear Gd(III)-complex of compound 38 exhibiting a $\mathrm{r}_{1}$ value of $13.6 \mathrm{~s}^{-1} \mathrm{mM}^{-1}\left(20 \mathrm{MHz}, 25^{\circ} \mathrm{C}\right)$. Compound 38 was prepared from the bis-indole derivative $\mathbf{3 9}$, which was attached to two units of dtpa using TBTU/TEA in DMSO, according to Scheme 11.

Scheme 11. Dtpa bis-indole derivative.

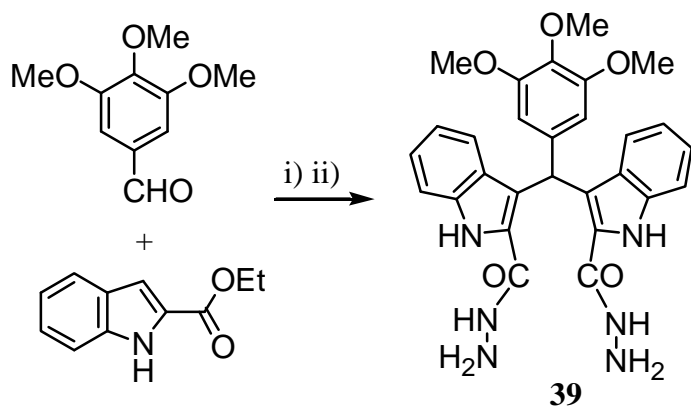

39

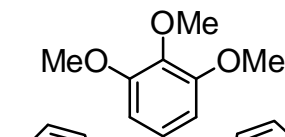

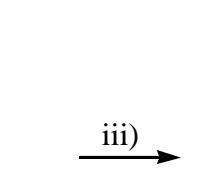

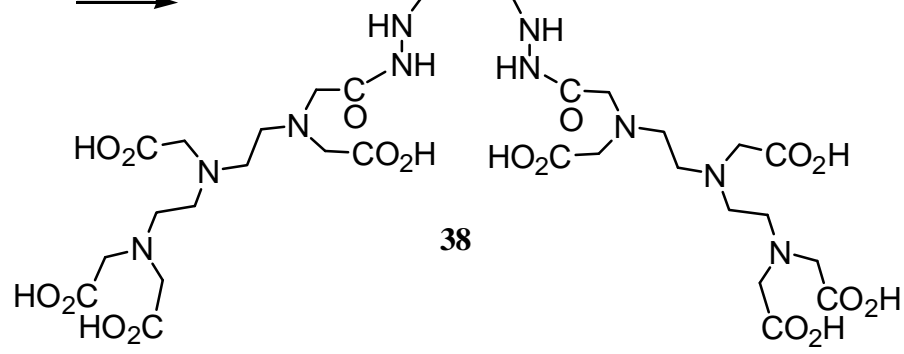

i) EtOH, $\mathrm{HCl}$, reflux; ii) $\mathrm{MeOH}, \mathrm{NH}_{2} \mathrm{NH}_{2}, \mathrm{Py}, 100{ }^{\circ} \mathrm{C}$; iii) ethylentriaminepentaacetic acid, TBTU/TEA, DMSO

Gd-complexes have been also produced to recognize molecules such as sialic acids, a generic term for the $\mathrm{N}$ - or $\mathrm{O}$-substituted derivatives of neuraminic acid, a nine-carbon monosaccharide containing a carboxyl group at the anomeric carbon. Glycoproteins or glycolipids containing sialic acids as terminal residues are often present in the cell surface or intracellular membranes.

Frullano et al. [30] synthesized a Gd-complex of $\mathbf{4 0}$ able to recognize and reversibly bind to sialic acid residues (Scheme 12), often proposed as diagnostic indicators in several diseases. Ligand $\mathbf{4 0}$ was synthesized from tri(ethylamine)amine (TREN) with two amine groups protected as tert-butoxycarbonyl (Boc) moieties and subsequent treatment with 2-methyl-2-thioimidazoline hydroiodide in refluxing ethanol. Removal of the Boc protecting groups in acidic medium afforded compound $\mathbf{4 1}$, which reacted with 2-formylphenylboronic acid giving the corresponding imine. Reduction of the 
latter and subsequent separation leaded to the monoamine 42. Finally, $\mathbf{4 0}$ was prepared by condensation between compound 42 and the dtpa-bis-anhydride (Scheme 12).

Scheme 12. Gd(III)-40 recognizing and reversibly binding to the sialic acid residues.

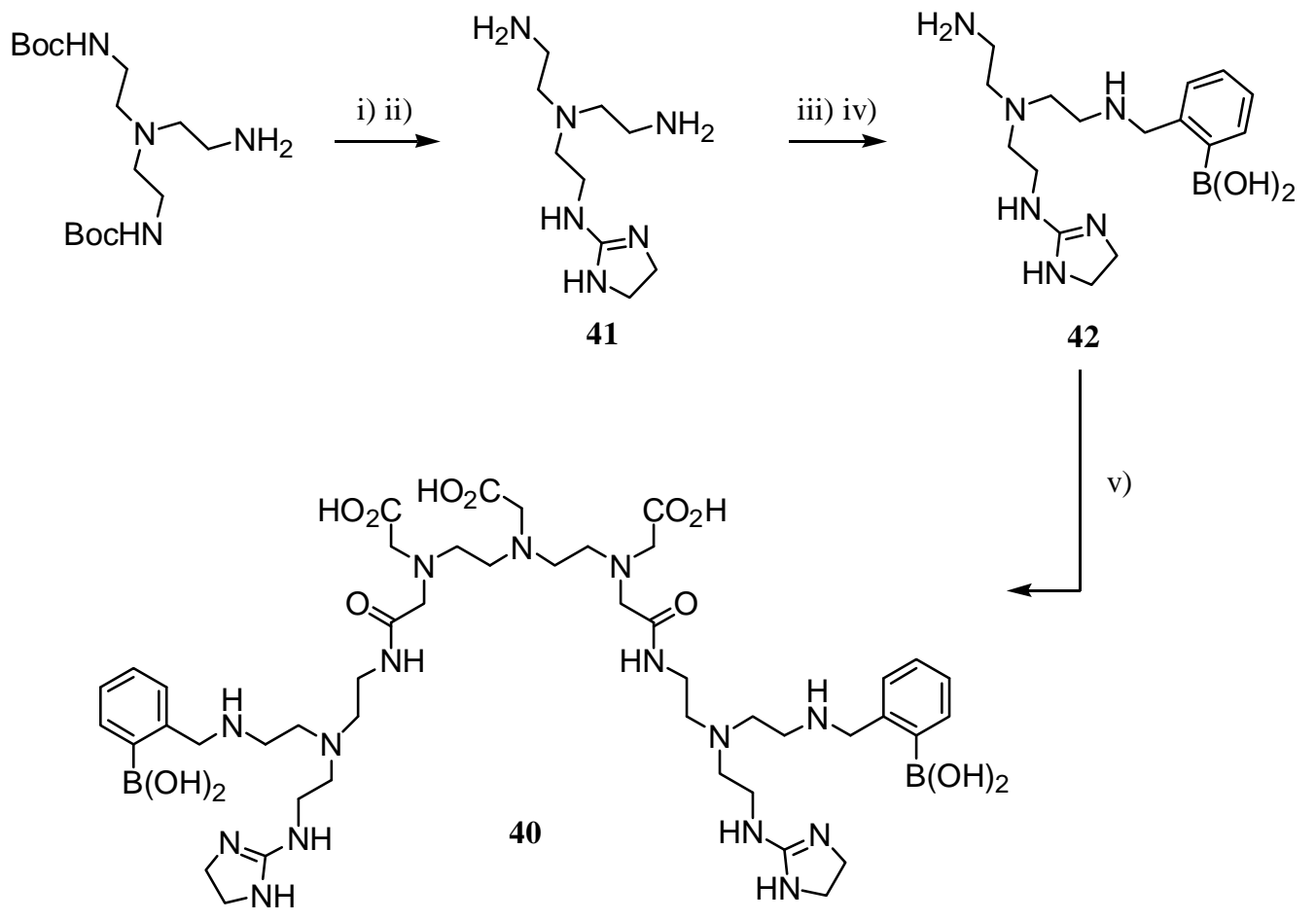

i) 2-methylthio-2-imidazoline hydroiodide, EtOH, reflux; ii) $\mathrm{HCl} 37 \% \mathrm{EtOH}$; iii) 2-formylphenylboronic acid, $\mathrm{MeOH}$, TEA; iv) $\mathrm{NaBH}_{4}$, MeOH; v) Dtpa-bisanhydride, zeolite KA, EtOH

One of the first CAs that included pyrimidine rings in its structure was the Mn(II) complex of $N, N^{\prime}$-dipyridoxylethylenediamine- $N, N^{\prime}$-diacetate 5,5'-bis(phosphonate) (DPDP, 43), considered the active component of Teslascan $^{\circledR}$, a contrast medium for hepatic MRI [31]. This complex was synthesized in 1989 from pyridine $\mathbf{4 4}$ by condensation with ethylenediamine and subsequent reduction of the corresponding imine affording compound 45. Alkylation of amine groups in $\mathbf{4 5}$ with bromoacetic acid in basic medium gave $\mathbf{4 3}$ (Scheme 13) [32].

Scheme 13. Synthesis of DPDP as chelating ligand for Mn(II).

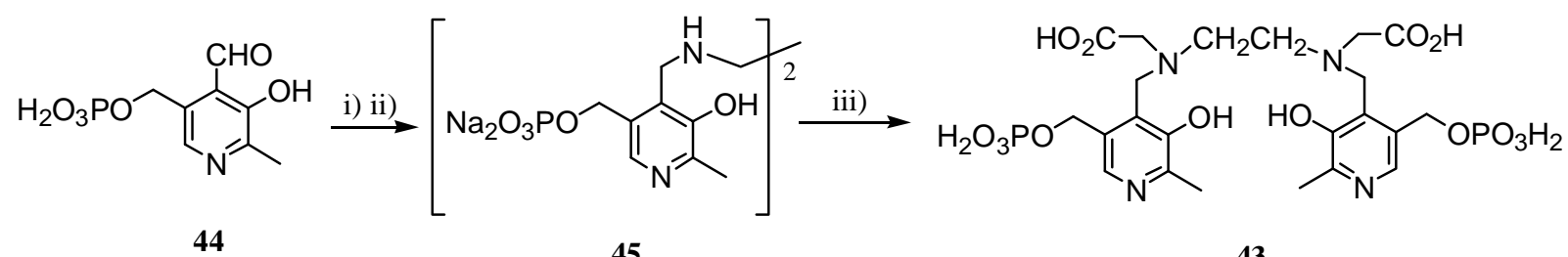

i) ethylenendiamine, $\mathrm{NaOH}, \mathrm{MeOH}$; ii) $\mathrm{H}_{2}$, $\mathrm{Pt} / \mathrm{C}$; iii) bromoacetic acid, $\mathrm{NaOH}$

Recently, 4-benzyloxy-5-pyrimidinone carboxylic acid $\mathbf{4 6}$ was reported as a building block to prepare several ligands through coupling with the corresponding amine. Two synthetic routes leading 
to 46 were reported (Scheme 14) [33]. One of them starts with self-condensation of $\mathbf{4 7}$ and subsequent in situ reaction with acetamidine, giving compound 48. Nitrogen methylation followed by hydroxyl group deprotection in an acidic medium and benzylation of the freed hydroxyl moiety at the 5-position yielded compound 49. Finally, oxidation of 49, using phase transfer conditions, afforded the acid $\mathbf{4 6 .}$ The second approach was a shorter one starting from diethyl oxalate and benzyl benzyloxyacetate. Condensation of both, in the same conditions mentioned above, leaded to ester $\mathbf{5 0}$, which by nitrogen methylation and basic hydrolysis of the ester group yielded the desired acid $\mathbf{4 6}$. Coupling of $\mathbf{4 6}$ with amines may produce a large series of hydroxypyrimidinones. Particularly, the Gd-complex of $\mathbf{5 1}$ exhibited a relaxivity value of $9.0 \mathrm{~s}^{-1} \mathrm{mM}^{-1}$ measured at $20 \mathrm{MHz}$ and $25{ }^{\circ} \mathrm{C}$.

Scheme 14. Two synthetic strategies to prepare 51.

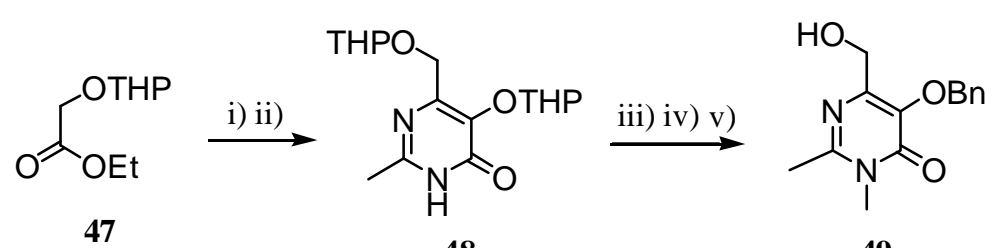

49

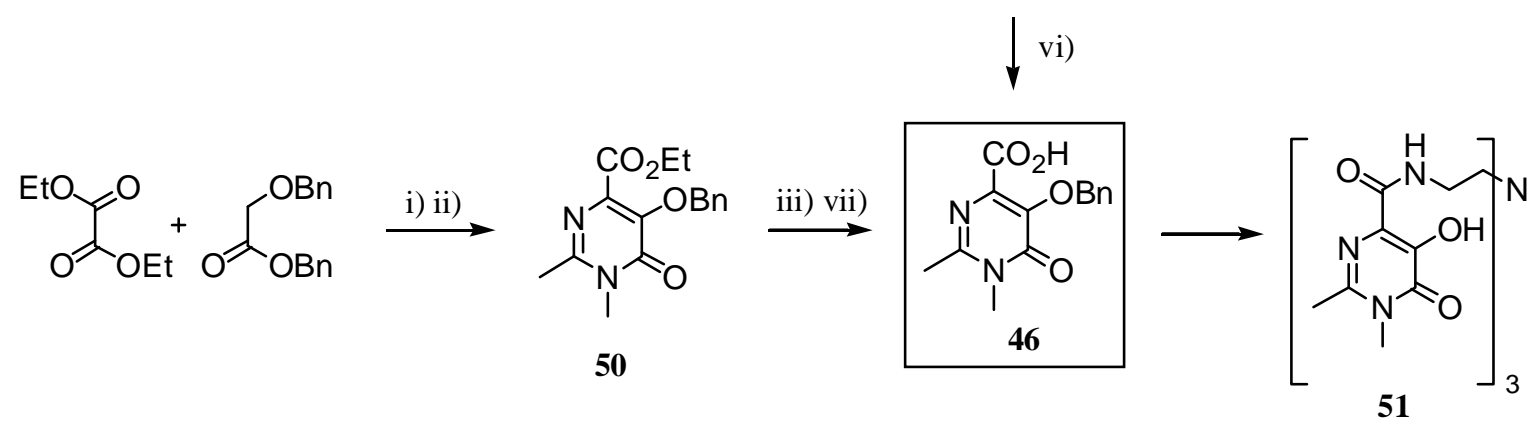

i) $\mathrm{Na}$ or $\mathrm{NaH}, \mathrm{Et}_{2} \mathrm{O}$ or THF; ii) acetamidine; iii) $\mathrm{NaH}$, DMF, MeI; iv) $\mathrm{H}^{+}$, $\mathrm{ROH}$; v) $\mathrm{K}_{2} \mathrm{CO}_{3}$, DMF, BnCl; vi) aq $\mathrm{NaOCl}$, $\mathrm{PT}$; vii) a) $\mathrm{KOH}, \mathrm{MeOH}$, b) $\mathrm{H}_{3} \mathrm{O}^{+}$

In 2003, a new tripodal hydroxypyridonate Gd-complex of 52 was prepared (Scheme 15) and its stability constant and relaxometric studies were described [34]. Ligand 52 was obtained from thiazolide 53 by coupling with glycine to give compound 54 .

\section{Scheme 15}<smiles>Cn1ccc(C(=O)N2CCSC2=S)c(Br)c1=O</smiles>

53

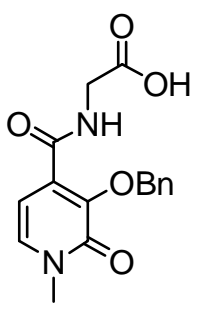

54

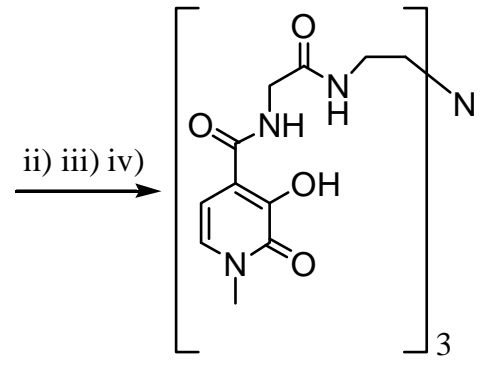

52

i) $\mathrm{NaOH}$; ii) NHS, DCC; iii) TREN; 5\% Pd/C, $\mathrm{H}_{2}$ 
Activation of 54 using $N$-hydroxy-succinimide (NHS), followed by amidation with TREN and subsequent benzyloxy group deprotection afforded compound 52. The corresponding Gd(III)-complex showed improved relaxivity $\left(6.6 \mathrm{~s}^{-1} \mathrm{mM}^{-1}\right.$ at $20 \mathrm{MHz}$ and $\left.298 \mathrm{~K}\right)$, compared to the CAs normally used in clinical diagnosis. However, its stability constant decreased slightly with respect to the analogous $\mathbf{5 1}$ without the glycine unit. Bis-hydroxypyridonate chelates were investigated, the MR imaging investigations and biodistribution being reported [35].

More recently, Pierre et al. [36] described a new dendrimeric Gd(III) chelator 55, including 12 hydroxyl groups to ensure the overall solubility in water, and exibiting a $r_{1}$ values of 1.6 and 1.8 times greater than its corresponding monomer at 20 and $90 \mathrm{MHz}$, respectively $\left(14.3\right.$ and $18.0 \mathrm{~s}^{-1} \mathrm{mM}^{-1} 25^{\circ} \mathrm{C}$, respectively ). Ligand 55 derived from hydroxypyridonate was synthesized according to Scheme 16.

Scheme 16. Dendrimeric chelating ligand derived from hydroxypyridonate.<smiles>CC(C)CNC(=O)CC(NC(=O)CC(N)C(=O)NC(CC(=O)NCc1ccccc1)C(=O)NCc1ccccc1)C(=O)NCc1ccccc1</smiles>

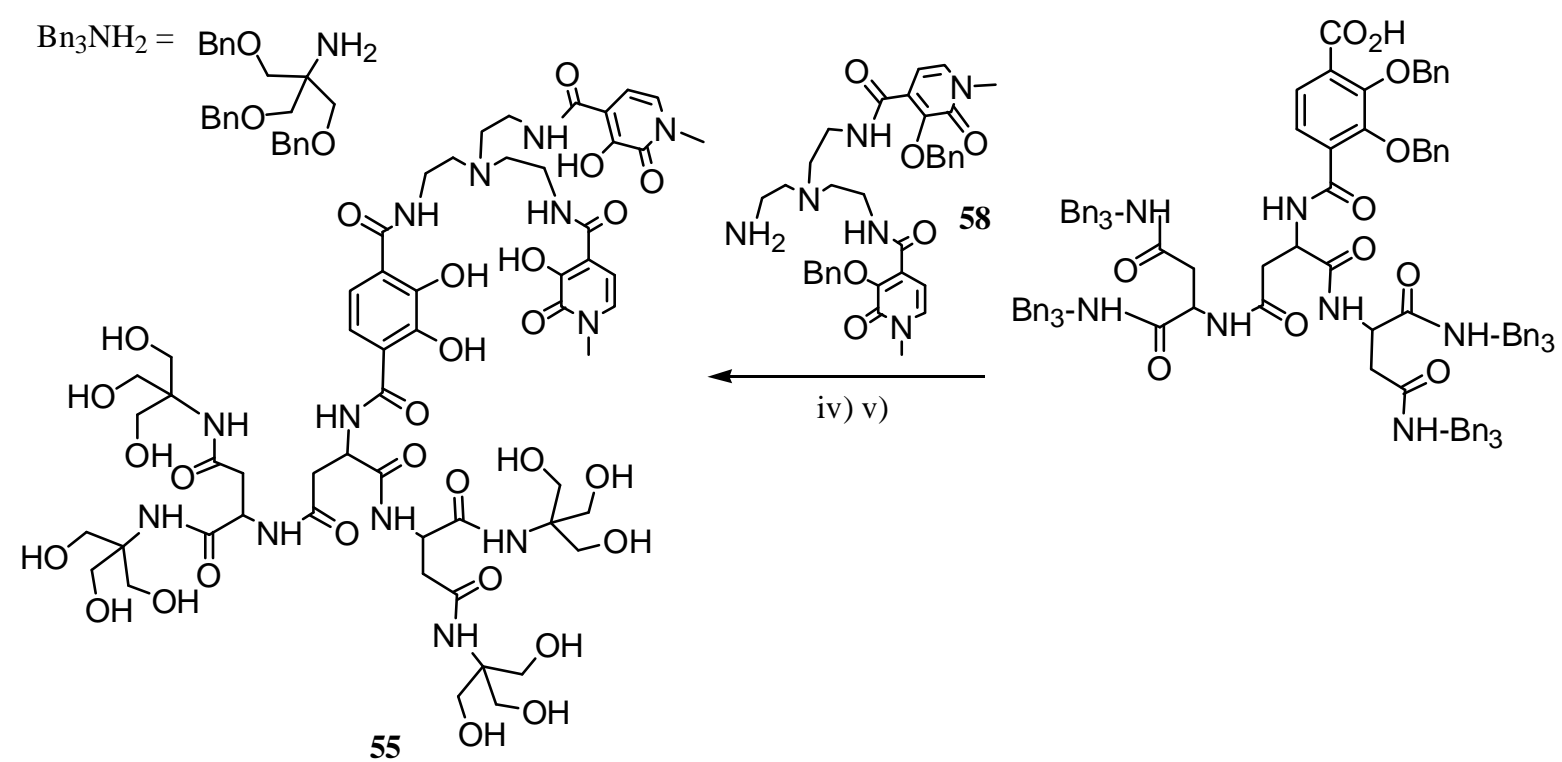

i) HATU, DIPEA, DMA, $20^{\circ} \mathrm{C}$; ii) TFA, $\mathrm{CH}_{2} \mathrm{Cl}_{2}, 20^{\circ} \mathrm{C}$; iii) (a) $\mathrm{C}_{2} \mathrm{O}_{2} \mathrm{Cl}_{2}$, toluene, DMF, $20^{\circ} \mathrm{C}$, (b) DIPEA, THF, $20{ }^{\circ} \mathrm{C}$; iv) HATU, DIPEA, $\mathrm{CH}_{2} \mathrm{Cl}_{2}, 20^{\circ} \mathrm{C}$; v) $\mathrm{H}_{2}$, Pd/C, acetic acid

Reaction of tris-benzyloxyethanolamine and $N$-tert-butoxycarbonylaminoaspartic acid in the presence of the coupling reagent, HATU ( $N$-[(dimethylamino)-1 $H$-1,2,3-triazolo-[4,5-b]pyridin-1ylmethylene]- $N$-methylmethanaminium hexafluorophosphate $N$-oxide), and subsequent deprotection of the amino group in an acidic medium led to compound 56. Coupling of $\mathbf{5 6}$ with an additional aspartic acid unit and subsequent deprotection of the amino group afforded 57. Amidation reaction between 2,3-benzyloxyterephtalic chloride and 57, followed by coupling with compound 58, and 
hydrogenolysis of benzyl moieties yielded ligand 55. This chelating ligand coordinated one Gd(III) ion showing two water molecules in the inner-sphere.

\subsection{CAs derived from macrocyclic ligands}

The development of novel generations of macrocyclic CAs for MRI, such as Dota derivatives, is an important area of research because of the higher thermodynamic and kinetic stability of these lanthanide complexes in comparison with the linear CAs [37]. Three important key intermediates are used to prepare macrocyclic ligands based on the cyclen skeleton: monoalkylated cyclen 59 [38], 1,7disubstituted-1,4,7,10-tetraazacyclododecanes 60 [39] and the 1,4,7-tris(tert-butoxycarbonylmethyl)1,4,7,10-tetraazacyclododecane hydrobromide salt 61 [40] (Figure 5).

Figure 5. Cyclen derivatives used to synthesize the most useful macrocyclic CAs.

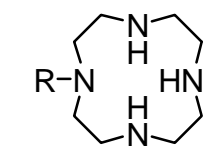

59

$\mathrm{R}=$ Benzyl, allyl, $\mathrm{CH}_{2} \mathrm{CO}_{2} \mathrm{Et}$, $-\left(\mathrm{CH}_{2}\right) \mathrm{n} \mathrm{OH}$

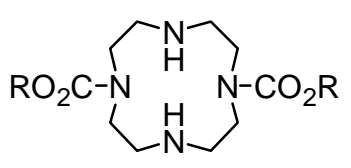

60

$\mathrm{R}=\mathrm{Me}$, Et, vinyl, benzyl

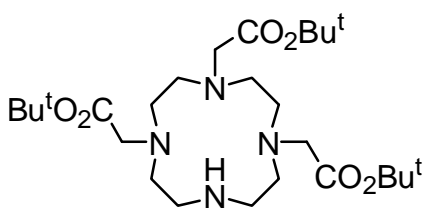

$\mathrm{BrH}$

61

Ligand 62 containing a tetrazolylmethyl arm was prepared from compound $\mathbf{6 1}$ according to Scheme 17 [41]. Compound $\mathbf{6 1}$ was alkylated with freshly distilled chloroethylnitrile under heterogeneous conditions followed by treatment with $\mathrm{TMS}^{-\mathrm{N}_{3}}$, in the presence of $\mathrm{Bu}_{2}$-SnO, yielding the corresponding tetrazole derivative, which by acid hydrolysis afforded 62 ( $\mathrm{r}_{1}$ of Gd-62 was $4.8 \mathrm{~s}^{-1}$ $\mathrm{mM}^{-1}$ measured at $60 \mathrm{MHz}$ and $37^{\circ} \mathrm{C}$ ).

\section{Scheme 17}

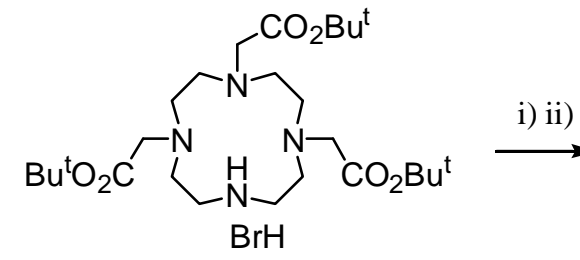

61

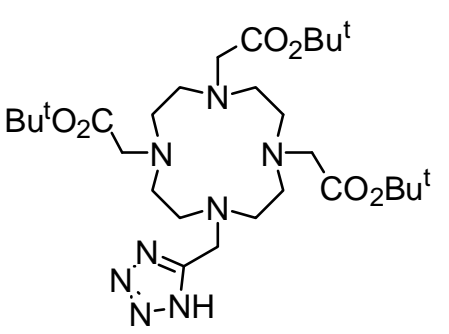

$\mathrm{N}-\mathrm{NH}$

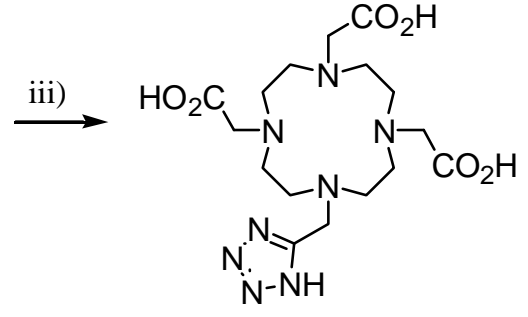

62

i) $\mathrm{ClCH}_{2} \mathrm{CN}, \mathrm{KI}, \mathrm{K}_{2} \mathrm{CO}_{3}$ acetonitrile, reflux; ii) a) $\mathrm{TMS}-\mathrm{N}_{3}, \mathrm{Bu}_{2}-\mathrm{SnO}$, toluene, reflux. b) $5 \%$ aq. $\mathrm{HCl}$; iii) $12 \mathrm{~N} \mathrm{HCl} \mathrm{reflux.}$

The $\mathrm{pH}$ environment of a complex can modify some of the determinant factors that contribute to the relaxivity of CAs, such as the number of water molecules $(q)$ in the inner-sphere of the complex, or even the second coordinating sphere. Pyridylmethyltetraamides 63 derived from Dota were studied as $\mathrm{pH}$ dependent CAs [42]. Gd-63b showed a $\mathrm{r}_{1}$ values of 5.6 and $4.1 \mathrm{~s}^{-1} \mathrm{mM}^{-1}$ at $\mathrm{pH}$ of 8.5 and 3.3, respectively (20 MHz). Compounds 63 were prepared by alkylation of cyclen with the corresponding chloroacetamide 64 (Scheme 18). Ligands 64a-b were obtained by reaction of chloroacetyl chloride 
and the corresponding amine. Compound 64b was synthesized from 2-hydroxypicolinic acid by esterification with methanol, transformation of the ester in its amide by reaction with ammonia and subsequent reduction with borane giving amine $\mathbf{6 5}$. The protection of the hydroxy group as benzyloxy moiety in 65 was carried out in three steps: i) protection of the amine as tert-butylcarbamate, ii) benzoylation of hydroxyl group and, iii) deprotection of amine group in acidic medium affording compound 66.

Scheme 18. Pyridylmethyltetraamides as $\mathrm{pH}$ responsive CAs.

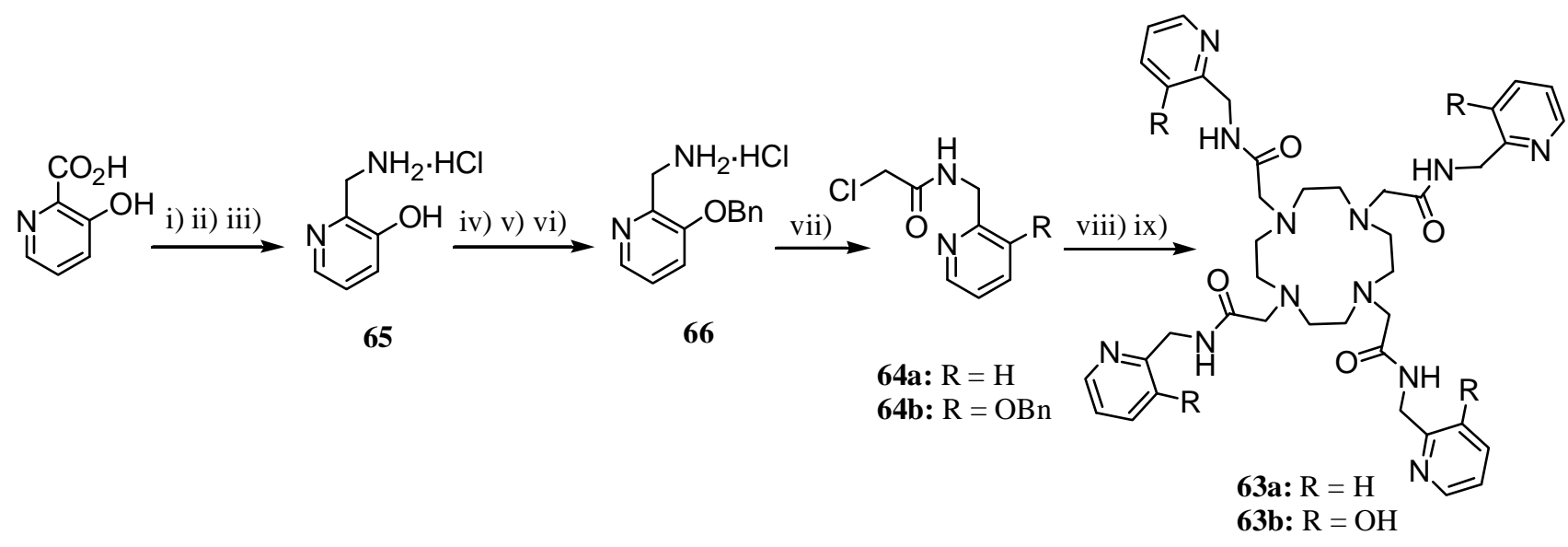

i) $\mathrm{MeOH}, \mathrm{H}_{2} \mathrm{SO}_{4}$; ii) $\mathrm{NH}_{3}$ (aq); iii) a) $\mathrm{BH}_{3}$, THF; b) $2 \mathrm{M} \mathrm{HCl}$; iv) (Boc) ${ }_{2} \mathrm{O}, \mathrm{MeOH}, \mathrm{NaHCO}_{3}$, $\mathrm{H}_{2} \mathrm{O}$; v) $\mathrm{BnBr}_{2} \mathrm{~K}_{2} \mathrm{CO}_{3}$, acetonitrile; vi) $\mathrm{HCl}$, EtOH; vii) chloroacetyl chloride, THF, $\mathrm{NaHCO}_{3}, \mathrm{H}_{2} \mathrm{O}$; viii) cyclen, $\mathrm{K}_{2} \mathrm{CO}_{3}$, acetonitrile; ix) $\mathrm{H}_{2}$, $\mathrm{Pd} / \mathrm{C}$, EtOH (only to synthesize 63b)

Another example of a CA displaying $\mathrm{pH}$ dependent relaxivity is the Gd(III)-complex of ATPconjugated DO3A 67, reported by Ratnakar and Alexander $\left(6.5 \mathrm{~s}^{-1} \mathrm{mM}^{-1}\right.$ measured at $24 \mathrm{MHz}, 308 \mathrm{~K}$ and $\mathrm{pH}$ of 8.5) [43]. Compound 67 was prepared from cyclen by trialkylation using bromoacetic acid and subsequent reaction with 1,3-bromopropane in basic medium leading to compound $\mathbf{6 8}$. Treatment of 68 with ATP disodium salt in water afforded 67 (Scheme 19).

Scheme 19. ATP-conjugated DO3A 67 which its Gd(III)-complex showing pH dependence relaxivity.

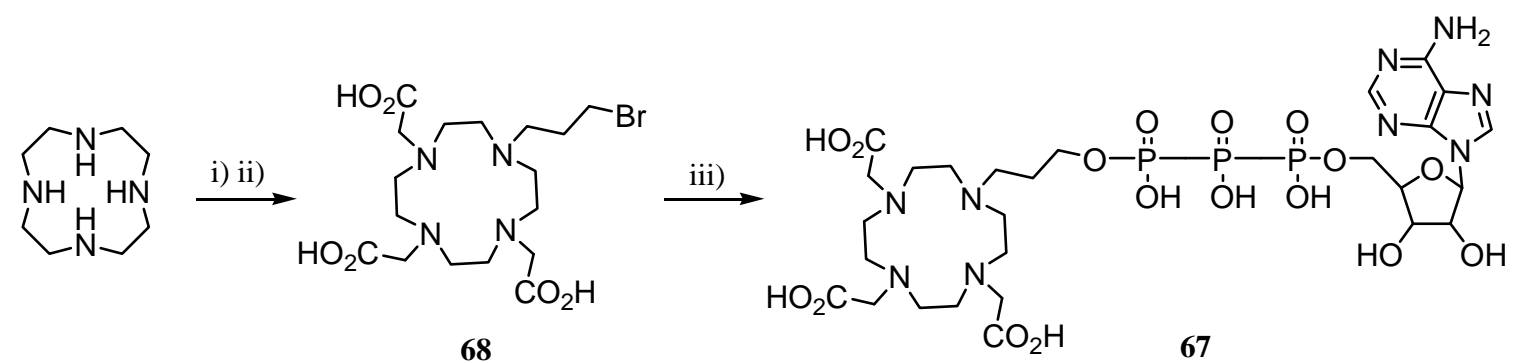

i) chloroacetic acid, $\mathrm{H}_{2} \mathrm{O}, \mathrm{NaOH}$ (pH 10), $-4^{\circ} \mathrm{C}$; ii) 1,3-dibromopropane, DMF, $\mathrm{H}_{2} \mathrm{O}$, triethylamine; iii) adenosine $5^{\prime}$ triphosphate disodium salt, $\mathrm{H}_{2} \mathrm{O}$, rt

Several contributions have reported novel series of tetraazamacrocycles containing one pyridine ring as part of the macrocycle. Their lanthanide complexes generally showed high stability and improved relaxivity. These heptadentate ligands form stable complexes with lanthanide ions, allowing the coordination of two water molecules in the inner-sphere and consequently providing higher 
relaxivity than Dota chelates. In general these complexes are characterized by a relatively fast water exchange rate as compared to the octacoordinated ligands. Scheme 20 shows the synthetic approach to prepare 69 [44]. Ligand 69a was synthesized by reaction of 1,4,7-tritosyl-1,4,7-triazaheptane with bis(2,6-chloromethyl)pyridine, followed by deprotection of the amine groups in an acidic medium yielding compound 70a. Alkylation of 70a with chloroacetic acid in the presence of sodium carbonate, and subsequent treatment in acidic medium yielded 69a (Gd-69 showed a $\mathrm{r}_{1}$ of $6.9 \mathrm{~s}^{-1} \mathrm{mM}^{-1}$ at $20 \mathrm{MHz}$ and $25{ }^{\circ} \mathrm{C}$ ). Compounds 69b-c were synthesized from the corresponding triprotected amine via the macrocycles 70b-c. The latter reacted with methyl chloroacetate as alkylating agent yielding the corresponding esters, which were hydrolyzed using $\mathrm{KOH}$ in methanol. Complexes Gd-69b and Gd-69c exhibited a $\mathrm{r}_{1}$ values of 5.9 and $6.3 \mathrm{~s}^{-1} \mathrm{mM}^{-1}$, respectively (20 $\mathrm{MHz}$ and $25^{\circ} \mathrm{C}$ ).

Scheme 20.

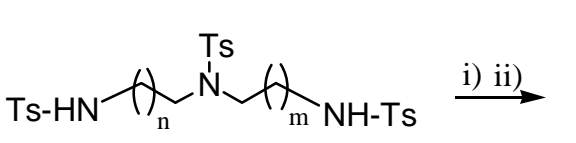

a: $\mathrm{n}=\mathrm{m}=1$

b: $\mathrm{n}=\mathrm{m}=2$

c: $\mathrm{n}=1, \mathrm{~m}=2$

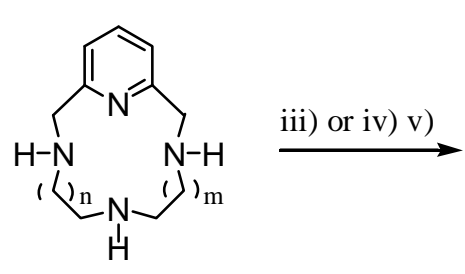

70

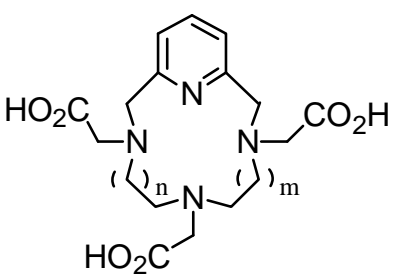

69

i) bis-(2,6-chloromethyl)pyridine, $\mathrm{Na}_{2} \mathrm{CO}_{3}$, acetonitrile, reflux; ii) $\mathrm{HBr}$, $\mathrm{AcOH}$, phenol, reflux; iii) a) $\mathrm{KOH}$, b) $\mathrm{KOH}$, chloroacetic acid, $\mathrm{H}_{2} \mathrm{O} 80{ }^{\circ} \mathrm{C}$, c) $2 \mathrm{~N} \mathrm{HCl}$, ( $=\mathrm{m}=1$ ); iv) a) methyl chloroacetate, $\mathrm{Ag}_{2} \mathrm{CO}_{3}$, THF, b) $\mathrm{H}_{3} \mathrm{O}^{+} \mathrm{H}_{2} \mathrm{~S}$;

v) $\mathrm{KOH}, \mathrm{MeOH}(\mathrm{n}=\mathrm{m}=1$ and $\mathrm{n}=1, \mathrm{~m}=2)$

Analogous systems $\mathbf{7 1}$ with substitutents on a pyridine ring were prepared using a similar synthetic approach to that employed to obtain $\mathbf{6 9}$, starting from the corresponding bis(2,6-chloromethyl)pyridine derivative (Figure 6) [45].

Figure 6.

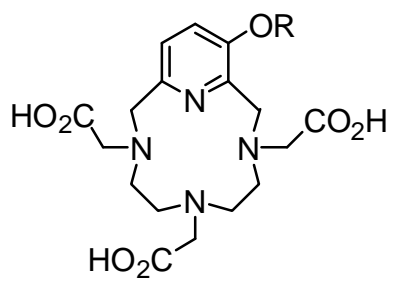

71a: $\mathrm{R}=\mathrm{CH}_{2}-\mathrm{C}_{6} \mathrm{H}_{4}-\mathrm{Br}-\mathrm{p}$

71b: $\mathrm{R}=\mathrm{C}_{12} \mathrm{H}_{25}$

Their corresponding Gd(III)-complexes depicted improved relaxivity with respect to 69 ( $\mathrm{r}_{1}=8.25$ $\mathrm{s}^{-1} \mathrm{mM}^{-1}$ measured at $20 \mathrm{MHz}$ and $25{ }^{\circ} \mathrm{C}$, for Gd-71a). Studies on the binding of the Gd(III)-71a to biomacromolecules such as the human serum albumin (HSA), were described and even the formation of the inclusion compounds using $\beta$-cyclodextrins and poly- $\beta$-cyclodextrins were reported. These non covalent adducts showed higher relaxivity due to the reduced motion of the corresponding Gd(III)complexes, becoming well tolerated in animal tests. Gd(III)-71b was considered as micelar CAs, its relaxivity depending on concentration (maximum value of $\mathrm{r}_{1}$ was $29.2 \mathrm{~s}^{-1} \mathrm{mM}^{-1}$ at $20 \mathrm{MHz}, 25{ }^{\circ} \mathrm{C}$ and $1.5 \mathrm{mM})$. 
The relaxivity of pyridine-based complexes can be improved through the introduction of polar moieties supported over the heterocyclic ring, a circumstance probably improving the effects of the second coordination sphere. An example of that is the Gd(III)-complex of macrocycle 72, containing two free hydroxyl groups, with $\mathrm{r}_{1}$ of $8.5 \mathrm{~s}^{-1} \mathrm{mM}^{-1}$ at $20 \mathrm{MHz}$ and $25{ }^{\circ} \mathrm{C}$ [23]. Ligand 72 was prepared by double Mannich reaction between 3,5-dihydroxypyridine, paraformaldehyde and amine $\mathbf{7 3}$ followed by treatment with neat TFA-anisole (Scheme 21).

Scheme 21.

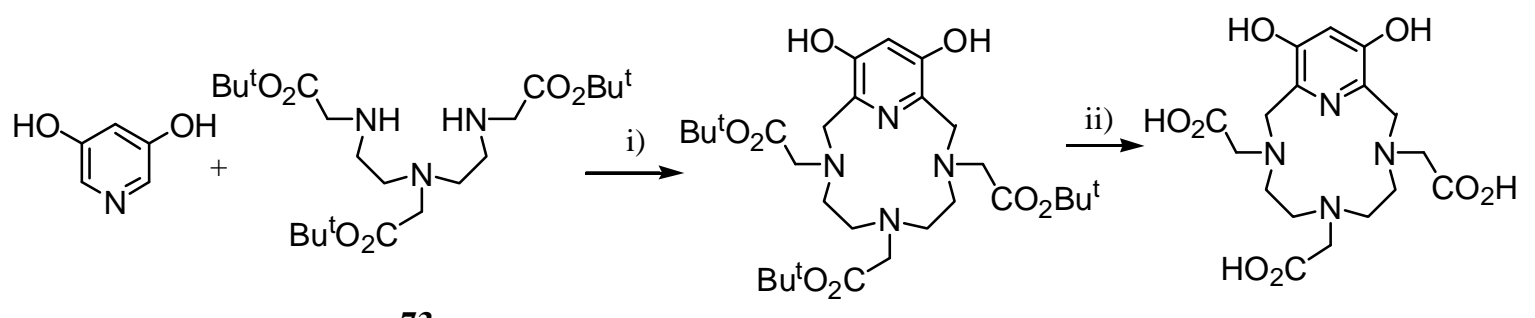

73

i) $\left(\mathrm{CH}_{2} \mathrm{O}\right) \mathrm{n}$, tartaric acid, $\mathrm{MeOH}$, reflux; ii) TFA, anisole

On the other hand, inclusion of the methylenephosphonic arm on triamine backbone of these macrocycles induced higher relaxivity of the corresponding Gd(III)-complexes. Thus, the complex of $\mathbf{7 4}$ showed two water molecules in its inner-sphere and another water molecule bound to the phosphate group providing an important contribution to the higher relaxivity $\left(r_{1}=8.3 \mathrm{~s}^{-1} \mathrm{mM}^{-1}\right.$ at $20 \mathrm{MHz}$ and 25 ${ }^{\circ} \mathrm{C}$ ) [46]. Compound $\mathbf{7 4}$ was prepared from $\mathrm{N}$-tosylaziridine and diethyl aminomethylphophonate leading to the amine 75 (Scheme 22). Cyclization of $\mathbf{7 5}$ with bis(2,6-chloromethyl)pyridine in basic medium, deprotection of amine groups and subsequent alkylation of them afforded compound $\mathbf{7 4}$ in high overall chemical yield.

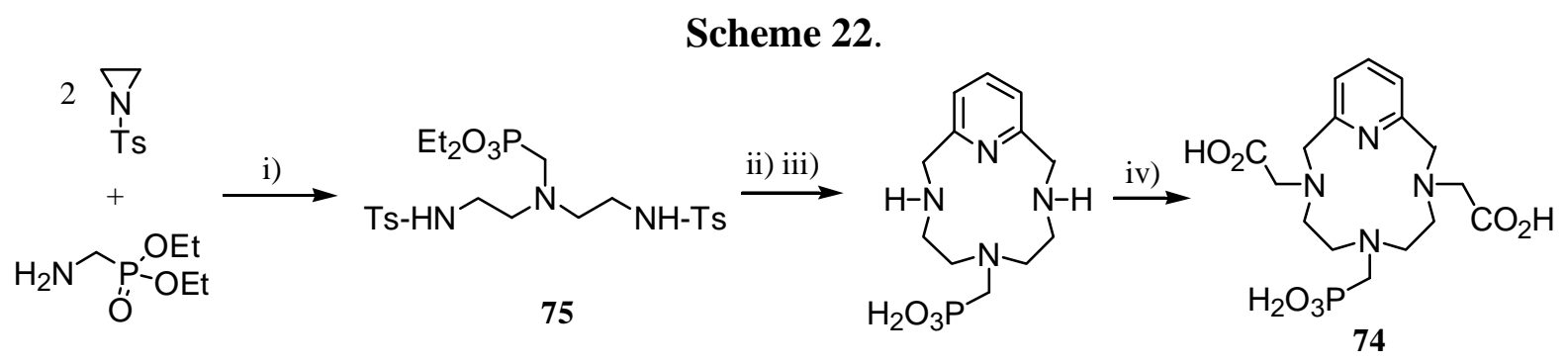

i) toluene, reflux; ii) bis(2,6-chloromethyl)pyridine, $\mathrm{K}_{2} \mathrm{CO}_{3}$;iii) $\mathrm{H}_{2} \mathrm{SO}_{4}$; iv) a) chloroacetic acid, $\mathrm{NaOH}$, b) $4 \mathrm{~N} \mathrm{HCl}$

A similar synthetic route (Scheme 23) was used to obtain the macrocycles $\mathbf{7 6}$ starting from the corresponding amino acids [47]. Relaxivity of their Gd(III)-76a-c was 8.3, 10.5, and $8.1 \mathrm{~s}^{-1} \mathrm{mM}^{-1}$ at 20 $\mathrm{MHz}$ and $25^{\circ} \mathrm{C}$, respectively, and in the range of the major of the heptadentate complexes. However, the inclusion of two phosphonate groups in $\mathbf{7 6 c}$ caused a decrease of the number of water molecules in the inner-sphere $(q=1)$ remaining two of those in second coordinating sphere $\left(q^{2 n d}=2\right)$. Esterification of the corresponding amino acid followed by reaction with two units of the $N$-tosylaziridine yielded compounds 77, which gave the corresponding macrocycles under the conditions mentioned above; deprotection of amine groups in 77a using acidic medium leaded to compound 78. While alkylation of the free amine groups in compound $\mathbf{7 8}$ using chloroacetic acid gave $\mathbf{7 6 a}$, treatment of $\mathbf{7 8}$ with phosphoric acid and paraformaldehyde yielded 76c. Ligand $\mathbf{7 6 b}$ was synthesized from $\mathbf{7 7 b}$ in five 
steps as follow: i) protection of hydroxyl group, ii) formation of macrocycle, iii) deprotection of amine groups, iv) alkylation of those and hydroxyl using methyl chloroacetate and, v) basic hydrolysis.

\section{Scheme 23.}

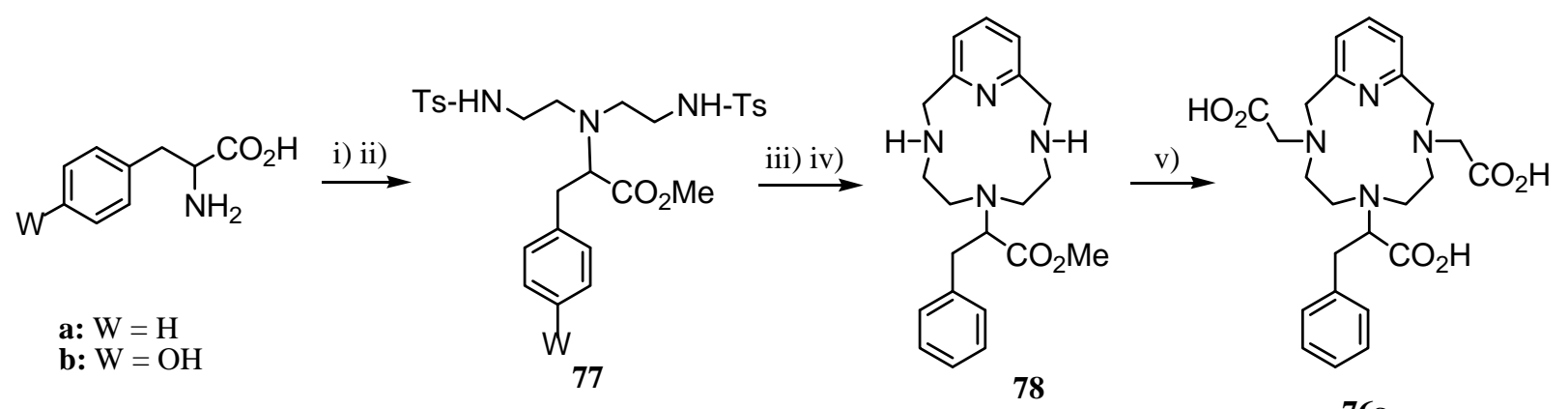

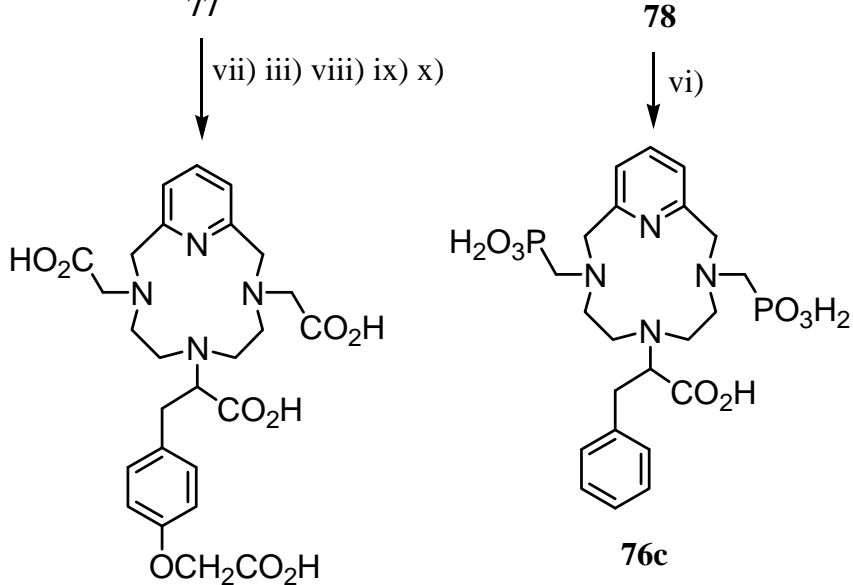

76a

76b

i) $\mathrm{SOCl}_{2}, 0^{\circ} \mathrm{C}, \mathrm{MeOH}$; ii) 1-tosylaziridine, toluene, reflux; iii) 2,6-bis(chloromethyl)pyridine, $\mathrm{K}_{2} \mathrm{CO}_{3}$ acetonitrile reflux; iv) $48 \% \mathrm{HBr}, \mathrm{PhOH}$, AcOH, reflux; v) chloroacetic acid, $\mathrm{KOH}, 80{ }^{\circ} \mathrm{C}$; vi) $\mathrm{H}_{3} \mathrm{PO}_{3}$, $\left(\mathrm{CH}_{2} \mathrm{O}\right) \mathrm{n} \mathrm{HCl}$, reflux; vii) ${ }^{\mathrm{t}} \mathrm{BuMe}{ }_{2} \mathrm{SiCl}$,

${ }^{\mathrm{i}} \mathrm{Pr}_{2} \mathrm{EtN}$, acetonitrile, $0{ }^{\circ} \mathrm{C}$; viii) $30 \% \mathrm{HBr}$, $\mathrm{AcOH}, 80{ }^{\circ} \mathrm{C}$; ix) methyl bromoacetate, $\mathrm{Ag}_{2} \mathrm{CO}_{3}$, acetonitrile, rt; $\mathrm{x}$ ) $\mathrm{KOH}, \mathrm{MeOH}$ $80^{\circ} \mathrm{C}$

Zheng et al. [48] have developed new lipophilic macromolecular chelators of lanthanide ions 79 for in vivo applications. Some types of cells can be labeled with these complexes in order to visualize cell migration in different biological systems. Compounds $\mathbf{7 9}$ were prepared by reaction of bis(2,6bromomethyl)pyridine and the corresponding amines and subsequent reaction with $\left(\mathrm{CF}_{3} \mathrm{CO}\right)_{2} \mathrm{O}$ to give compound 80, this last additional step being necessary to purify the corresponding amines (Scheme 24). Finally, treatment of $\mathbf{8 0}$ in basic medium and reaction of those with DTPA-bisanhydride afforded compounds 79.

Scheme 24. Lipophilic macromolecular chelators of lanthanide ions $\mathbf{7 9 .}$

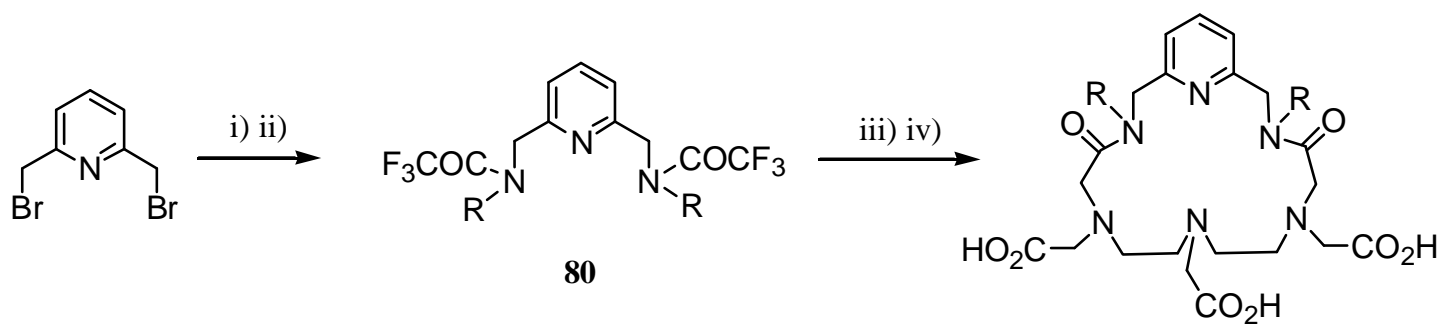


Multinuclear complexes based on 5,6-dihydro-1,10-phenanthrolin-5-yl-DO3A 81 were reported as complexes with higher molecular weights and consequently reduced motion of the complex and increased relaxivity [49] (Figure 7). Complex Gd(III)-81 spontaneously forms highly stable triscomplexes with $\mathrm{Fe}(\mathrm{II})$ and $\mathrm{Ni}(\mathrm{II})$ characterized because of their relaxivity is not dependent on the temperature in a $5-30{ }^{\circ} \mathrm{C}$ range. Relaxivity values reported for $\mathrm{Gd}-\mathbf{8 1}$ and $\mathrm{Fe}[\mathrm{Gd}-\mathbf{8 1}]_{3}$ were 3.7 and $36.6 \mathrm{~s}^{-1} \mathrm{mM}^{-1}$ at $20 \mathrm{MHz}$ and $37^{\circ} \mathrm{C}$, respectively.

Figure 7. Multinuclear complex based on 5,6-dihydro-1,10-phenanthrolin-5-yl-DO3A.

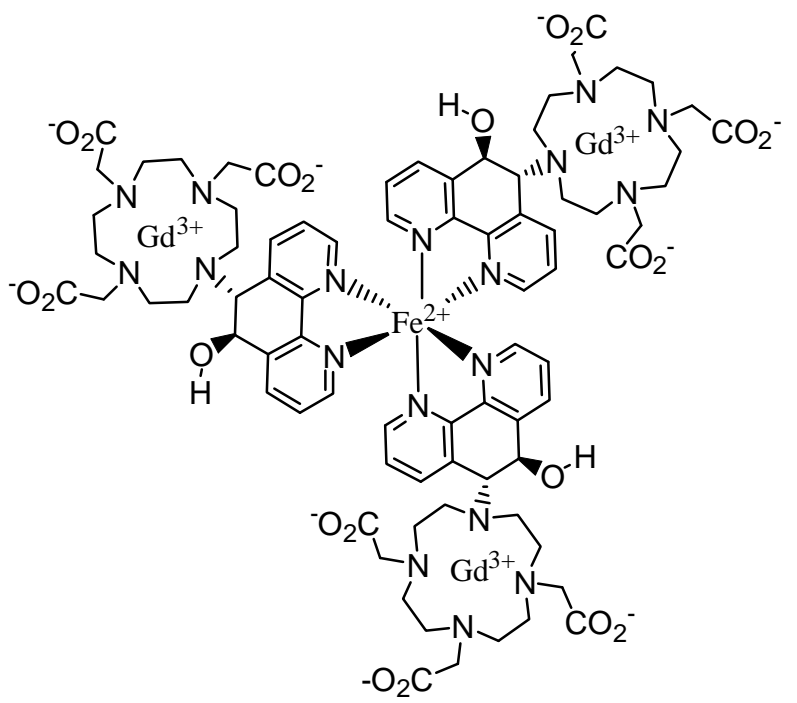

81

Ligand $\mathbf{8 1}$ was prepared from phenanthroline by epoxidation, subsequent reaction with cyclen derivative 82, followed by refluxing in $\mathrm{HCl}$ in $\mathrm{MeOH}$ affording compound $\mathbf{8 3}$. Finally, alkylation of $\mathbf{8 3}$ yielded the desired compound $\mathbf{8 1}$ (Scheme 25).

\section{Scheme 25.}<smiles>CCCc1cccnc1-c1ccccn1</smiles><smiles>CC(=O)NC1c2ncccc2-c2ncccc2C1O</smiles><smiles>O[C@H]1Cc2cccnc2-c2ncccc2[C@H]1O</smiles>

83

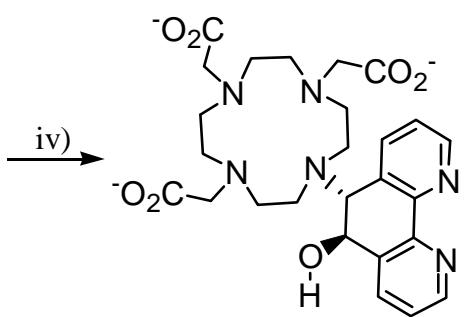<smiles>[CH]1N2CCN3CCN1CCN3CC2</smiles>

81

82

i) $\mathrm{NaOCl}, \mathrm{Na}_{2} \mathrm{HPO}_{4}$, (n-butyl) ${ }_{4} \mathrm{~N}^{+} \mathrm{HSO}_{4}^{-}$; ii) $\mathrm{X}, \mathrm{LiClO}_{4}$, acetonitrile; iii) $\mathrm{ClH}$ in $\mathrm{MeOH}$, b) $\mathrm{K}_{2} \mathrm{CO}_{3}$, acetonitrile; iv) $\mathrm{BrCH}_{2} \mathrm{CO}_{2} \mathrm{~K}, \mathrm{MeOH}, \mathrm{K}_{2} \mathrm{CO}_{3}$ 


\section{Concluding Remarks and Future Perspectives}

We have described above the main synthetic strategies used to produce heterocyclic CAs, a family of ligands depicting very appropriate stability and relaxivity properties for MRI. Basically, most of them are produced through two general organic reactions, namely amine alkylations or amidation. In general heterocycles provide good electron donor ligands suitable for improving the chelating capacity of the earlier complexones. The present review provides an adequate frame to analyze the importance of the heterocyclic ring in determining the coordination chemistry, the relaxivity and the stability properties of the resulting complexes.

On these grounds, the use of heterocyclic CA's is expected to increase in the future. The possibilities to obtain physiologically responsive agents, reflecting tissue properties beyond anatomy has already started [50]. Further improvements are expected from the combination of novel synthetic approaches and updated MR imaging techniques, as Magnetization Transfer [51]. The combination of both, synthetic and MRI approaches will certainly exceed the capabilities of their independent use. As a complementary field, the development of heterocyclic contrast agents useful for in vivo spectroscopy and spectroscopic imaging of $\mathrm{pH}$ and $\mathrm{pO}_{2}$ in healthy and pathological tissues, constitutes an area of growing interest [52-55]. The combination of spectroscopic and imaging approaches in multiparametric studies will further enhance the diagnostic potential of these new methods [56]. Finally, the development of multimodal heterocyclic probes, active in different imaging modalities (MRI, MRS, PET), is currently envisioned as one of the most attractive goals for the immediate future.

\section{Acknowledgements}

This work was supported in part by: CTQ2006-06505/BQU to PB, SAF 2004-02145, NAN200409125-C07-03, FIS C03/10, FIS C03/08, FIS G03/155 to SC, European Community MEDITRANS 2006; Integrated EU Project FP6-2004-NMP-NI-4/IP 026668-2 and S-BIO/0179/2006 from the Community of Madrid to PB and SC.

\section{References and Notes}

1. Mather, S. J. Design of radiolabelled ligands for the imaging and treatment of cancer. Mol. Biosyst. 2007, 3, 30-35.

2. Russell, R. R.; Zaret, B. L. Nuclear cardiology: Present and future. Curr Probl. Cardiol. 2006, 31, 557-629.

3. Zhang, H.; Maki, J. H.; Prince, M. R. 3D Contrast-enhanced MR angiography. J. Magn. Reson. Imaging 2007, 25, 13-25.

4. Deguchi, J-o.; Aikawa, M.; Tung, C.-H.; Aikawa, E.; Kim, D.-E.; Ntziachristos, V.; Weissleder, R.; Libby, P. Inflammation in atherosclerosis. Visualizing matrix metalloproteinase action in macrophages in vivo. Circulation 2006, 114, 55-62.

5. Kaufmann, B. A.; Wei, K.; Lindner, J. R. Contrast echocardiography. Curr. Probl. Cardiol. 2007, 32, 51-96. 
6. Jacquier, A.; Higgins, C. B.; Saeed, M. MR imaging in assessing cardiovascular interventions and myocardial injury. Contrast Media Mol. Imaging 2007, 2, 1-15.

7. Fu, X.; Tang, P-Z.; Kula, N. S.; Baldessarini, R.; Tanagnan, G.; Innis, R. B.; Baldwin, R. M. Synthesis, receptor potency, and selective of halogenated diphenylpiperidines as serotonin $5-\mathrm{HT}_{2 \mathrm{~A}}$ ligands for PET or SPECT brain imaging. J. Med. Chem. 2002, 45, 2319-2324.

8. Marinelli, E. R.; Diamantidis, A. G.; Emswiler, J.; Fan, H.; Neubeck, R.; Pillai, K. M. R.; Wagler, T. R.; Chen, C.-K.; Natalie, K.; Soundararajan, N.; Ranganathan, R. S. Heterocyclic non-ionic Xray contrast agents $\mathrm{V}$ : a facile conversion of 2-tetrahydrofuroamidas into $\alpha$-hydroxy- $\delta$ valerolactams and a general synthesis of lactams conjugated to 2,4,6-triiodoisophthalamides. Tetrahedron 1996, 52, 11177-11214.

9. Ntziachristos, V.; Yodh, A. G.; Schnall, M.; Chance, B. Concurrent MRI and diffuse optical tomography of breast following indocyanine green enhancement. Proc. Natl. Acad. Sci. USA 2000, 97, 2767-2772.

10. Licha, K.; Riefke, B.; Ntziachristos, V.; Becker, A.; Chance, B.; Semmler, W. Hydrophilic cyanine dyes as contrast agents for near-infrared tumor imaging: synthesis, photophysical properties and spectroscopic in vivo characterization. Photochem. Photobiol. 2000, 73, 392-398.

11. a) Merbach, A. E.; Tóth, E. The Chemistry of Contrast Agents in Medical Magnetic Resonance Imaging; John Wiley \& Sons, Ltd.: Chichester, UK, 2001; b) Gries, H. Contrast Agents I. Top. Curr. Chem. 2002, 221, 1-235.

12. a) Peters, J. A.; Huskens, J.; Raber, D. J. Lanthanide induced shifts and relaxation rate enhancements. Prog. Nucl. Magn. Reson. Spectrosc. 1996, 28, 283-350; b) Caravan, P. Strategies for increasing the sensitivity of gadolinium base MRI contrast agent. Chem. Soc. Rev. 2006, 35, 512-523.

13. a) Caravan, P.; Ellison, J. J.; McMurry, T. J.; Lauffer, R. B. Gadolinium(III) chelates as MRI contrast agents: structure, dynamics, and applications. Chem. Rev. 1999, 99, 2293-2352; b) Lauffer, R. B. Paramagnetic metal complexes as water proton relaxation agents for NMR imaging: theory and design. Chem. Rev. 1987, 87, 901-927.

14. a) Grant, D.; Refsum, H.; Rummeny, E.; Marchal, G. Mangafodipir trisodium, MnDPDP (Teslascan) - A new organ-specific contrast agent for MR imaging. Acta Radiol. 1997, 38, 623625; b) Roch, A.; Muller, R. N.; Gillis, P. Theory of proton relaxation induced by superparamagnetic particles. J. Chem. Phys. 1999, 110, 5403-5411; c) Colet, J. M.; Pierart, C.; Seghi, F.; Gabric, I.; Muller, R. N. Intravascular and intracellular hepatic relaxivities of superparamagnetic particles: An isolated and perfused organ pharmacokinetics study. J. Magn. Reson. 1998, 134, 199-205.

15. Miyake, H.; Watanabe, M.; Takemura, M.; Hasegawa, T.; Kojima, Y.; Inoue, M. B.; Inoue, M.; Fernando, Q. Novel optically-active bis(amino acid) ligands and their complexation with gadolinium. J. Chem. Soc., Dalton Trans. 2002, 1119-1125.

16. Platas-Iglesias, C.; Mato-Iglesias, M.; Djanashvili, K.; Muller, R. N.; Vander Elst, L.; Peters, J. A.; de Blas, A.; Rodríguez-Blas, T. Lanthanide chelates containing pyridine units with potential applications as contrast agents in magnetic resonance imaging. Chem. Eur. J. 2004, 10, 35793590. 
17. Mato-Iglesias, M.; Platas-Iglesias, C.; Djanashvili, K.; Peters, J. A.; Tóth, E.; Balogh, E.; Muller, R. N.; Vander Elst, L.; de Blas, A.; Rodríguez-Blas, T. The highest water exchange rate ever measured for a Gd(III) chelate. J. Chem. Soc., Chem. Commun. 2005, 4729-4731.

18. a) Mato-Iglesias, M.; Balogh, E.; Platas-Iglesias, C.; Tóth, E.; de Blas, A.; Rodríguez-Blas, T. Pyridine and phosphonate containing ligands for stable lanthanide complexation. An experimental and theoretical study to assess the solution structure. J. Chem. Soc., Dalton Trans. 2006, 54045415; b) Balogh, E.; Mato-Iglesias, M.; Platas-Iglesias, C.; Tóth, E.; Djanashvili, K.; Peters, J. A.; de Blas, A.; Rodríguez-Blas, T. Inorg. Chem. 2006, 45, 8719-8728.

19. López. P.; Seipelt, C. G.; Merkling, P.; Sturz, L.; Álvarez, J.; Dölle, A.; Zeidler, M. D.; Cerdán, S.; Ballesteros, P. N-2-(Azol-1(2)-yl)ethyliminodiacetic acids: a novel series of Gd(III) chelators as T2 relaxation agents for magnetic resonance imaging. Bioorg. Med. Chem. 1999, 7, 517-527.

20. Mayoral, E. P.; García-Amo, M.; López, P.; Soriano, E.; Cerdán, S.; Ballesteros, P. A novel series of complexones with bis- or bi structure as mixed ligands of paramagnetic contrast agents for MRI. Bioorg. Med. Chem. 2003, 11, 5555-5567.

21. Pérez-Mayoral, E.; García-Amo, M.; López-Larrubia, P.; Cerdán, S.; Ballesteros, P. Synthesis of new family of ligands with bispyrazole structure. Reactivity of bispyrazolylmethyl ethers. Heterocycles 2005, 65, 1691-1704.

22. a) Bretonnière, Y.; Mazzanti, M.; Pécaut, J.; Dunand, F. A.; Merbach, A. E. A new heptadentate tripodal ligand leading to a gadolinium complex with improved relaxation efficiency. J. Chem Soc., Chem. Commun. 2001, 621-622; b) Bretonnière, Y.; Mazzanti, M.; Pécaut, J.; Dunand, F. A.; Merbach, A. E. Solid-state and solution properties of the lanthanide complexes of a new heptadentate tripodal ligand: a route to gadolinium complexes with an improved relaxation. Inorg. Chem. 2001, 40, 6737-6745.

23. Aime, S.; Cavallotti, C.; Gianolio, E.; Giovenzana, G. B.; Palmisano, G.; Sisti, M. Mannich reaction as a new route to pyridine-based polyaminocarboxylic ligands. Org. Lett. 2004, 6, 12011204.

24. Chong, H.-S.; Garmestani, K.; Bryant, H.; Brechbiel, M. W. Synthesis of DTPA analogues derived from piperidine and azepane: potential contrast enhancement agents for magnetic resonance imaging. J. Org. Chem. 2001, 66, 7745-7750.

25. Cheng, T.-H.; Wang, Y.-M.; Lee, W.-T.; Liu, G.-C. Synthesis of two N'-2-pyridylmethyl and $N^{\prime}-$ 2-hydroxypropyl derivatives of diethylentriaminepentaacetic acid and the stabilities of their complexes with $\mathrm{Ln}^{3+}, \mathrm{Ca}^{2+}, \mathrm{Cu}^{2+}$ and $\mathrm{Zn}^{2+}$. Polyhedron 2000, 19, 2027-2037.

26. Pérez-Mayoral, E.; Soriano, E.; Cerdán, S.; Ballesteros, P. Experimental and theoretical study of lanthanide complexes based on linear and macrocyclic polyaminopolycarboxylic acids containing pyrazolylethyl arms. Molecules 2006, 11, 345-356.

27. Ruloff, R.; van Koten, G.; Merbach, A. E. Novel heteroditopic chelated for self-assembled gadolinium(III) complex with high relaxivity. J. Chem. Soc., Chem. Commun. 2004, 842-843.

28. Livramento, J. B.; Tóth, E.; Sour, A.; Borel, A.; Merbach, A. E.; Ruloff, R. High relaxiviy confined to a smart molecular space: a metallostar-based, potential MRI contrast agent. Angew. Chem. Int. Ed. 2005, 44, 1480-1484.

29. Parac-Vogt, T. N.; Kimpe, K.; Laurent, S.; Vander Els, L.; Burtea, C.; Chen, F.; Muller, R. N.; Ni, Y.; Verbruggen, A.; Binnemans, K. Synthesis, characterization, and pharmacokinetic evaluation 
of a potential MRI contrast agents containing two paramagnetic centers with albumin binding affinity. Chem. Eur. J. 2005, 11, 3077-3086.

30. Frullano, L.; Rohovec, J.; Aime, S.; Maschmeyer, T.; Prata, M. I.; Predroso de Lima, J. J.; Geraldes, C. F. C. G.; Peters, J. A. Towards targeted MRI: new MRI contrast agents for sialic acid detection. Chem. Eur. J. 2004, 10, 5205-5217.

31. Federle, M. P.; Chezmar, J. L.; Rubin, D. L.; Weinreb, J. C.; Freeny, P. C.; Semelka, R. C.; Brown, J. J.; Borrello, J. A.; Lee, J. K. T.; Mattrey, R.; Dachman, A. H.; Saini, S.; Harmon, B.; Fenstermacher, M.; Pelsang, R. E.; Harms, S. E.; Mitchell, D. G.; Halford, H. H.; Anderson, M. W.; Johnson, C. D.; Francis, I. R.; Bova, J. G.; Kenney, P. J-; Klippenstein, D. L.; Foster, G. S.; Turner, D. A.; Stillman, A. E.; Nelson, R. C.; Young, S. W.; Patt, R. H.; Rifkin, M.; Seltzer, S. E.; Gay, S. B.; Robinson, R. O.; Sherwin, P. F.; Ballerini, R. Safety and efficacy of Mangafodipir trisodium (MnDPDP) injection for hepatic MRI in adults: results of the U.S. multicenter phase III clinical trials (safety). J. Mag. Reson. Imaging 2000, 12, 186-197.

32. a) Rocklage, S. M.; Cacheris, W. P.; Quay, S. C.; Hahn, E. Manganese(II) $N, N^{\prime}-$ dipyridoxylethylenediamine-N,N'-diacetate 5,5'-bis(phosphonate). Synthesis and characterization of paramagnetic chelate for magnetic resonance imaging enhancement. Inorg. Chem. 1989, 28, 477-485; b) Schmidt, P. P.; Toft, K.; Skotland, T. Stability and transmetallation of the magnetic resonance contrast agent MnDPDP measured by EPR. J. Biol. Inorg. Chem. 2002, 7, 241-248; c) Halavaara, J.; Abo-Ramadan, U.; Makkola, A.; Aronen, H.; Häkkinen, A.-M. MnDPDP-enhanced magnetization transfer MR imaging: implications for effective liver imaging. Mag. Reson. Imaging 2003, 21, 47-50.

33. Sunderland, C. J.; Botta, M.; Aime, S.; Raymond, K. N. 6-Carboxamido-5,4hydroxypyrimidinones: a new class of heterocyclic ligands and their evaluation as gadolinium chelating agents. Inorg. Chem. 2001, 40, 6746-6756.

34. O’Sullivan, B.; Doble, D. M. J.; Thompson, M. K.; Siering, C.; Xu, J.; Otta, M.; Aime, S.; Raymond, K. N. The effect of ligand scaffold size on the stability of tripodal hydroxypyridonate gadolinium complexes. Inorg. Chem. 2003, 42, 2577-2583.

35. Thompson, M. K.; Misselwitz, B.; Tso, L. S.; Doble, D. M. J.; Schmitt-Willich, H.; Raymond, K. N. In vivo evaluation of gadolinium hydroxypyridonate chelates: initial experience as contrast media in magnetic resonance imaging. J. Med. Chem. 2005, 48, 3874-3877.

36. Pierre, V. C.; Botta, M.; Raymond, K. N. Dendrimeric gadolinium chelate with fast water exchange and high relaxivity at high magnetic field strength. J. Am. Chem. Soc. 2005, 127, 504505.

37. Ballesteros, P.; Soriano, E.; Pérez-Mayoral, E.; García-Amo, M.; Cerdán, S. Flexible tetraazamacrocycles as metal ligands. Their relevance in magnetic resonance imaging; In Strutural analysis of cyclic systems; Iriepa, I. Ed.; Research Singpost: Trivandrum, India, 2005; pp. 69-86.

38. Li, C.; Wong, W.-T. A convenient method for the preparation of mono $N$-alkylated cyclams and cyclens in high yields. Tetrahedron Lett. 2002, 43, 3217-3220.

39. Kovacs, Z.; Sherry, A. D. A general synthesis of 1,7-disubstituted 1,4,7,10-tetraazacyclododecanes. J. Chem. Soc., Chem. Commun. 1995, 185-186.

40. Dadabhoy, A.; Faulkner, S.; Sammes, P. G. Long wavelength for europium(III) luminescence based on acridone derivatives. J. Chem. Soc., Perkin Trans. 2 2002, 348-357. 
41. Aime, S.; Cravotto, G.; Geninatti Crich, S.; Giovenzana, G. B.; Ferrari, M.; Palmisano, G.; Sisti, M. Synthesis of the Gd(III) complex with tetrazole-armed macrocyclic ligand as a potential MRI contrast agent. Tetrahedron Lett. 2002, 43, 783-786.

42. a) Woods, M.; Sherry, A. D. Synthesis and luminescence studies of aryl substituted tetraamide complexes of europium(III): a new approach to $\mathrm{pH}$ responsive luminescent europium probes. Inorg. Chem. 2003, 42, 4401-4408; b) Woods, M.; Zhang, S.; Ebron, V. H.; Sherry, A. D. pHsensitive modulation of the second hydration sphere in lanthanide(III) tetraamide-DOTA complexes: a novel approach to smart MR contrast media. Chem. Eur. J. 2003, 9, 4634-4640.

43. Ratnakar, S. J.; Alexander, V. Synthesis and relaxivity studies of a gadolinium(III) complex of ATP-conjugated DO3A as a contrast enhancing agent for MRI. Eur. J. Inorg. Chem. 2005, 39183927.

44. Aime, S.; Botta, M.; Geninatti Crich, S.; Giovenzana, G. B.; Jommi, G.; Pagliarin, R.; Sisti, M. MRI Contrast agents: macrocyclic lanthanide(III) complexes with improved relaxation efficiency. J. Chem. Soc., Chem. Commun. 1995, 1885-1886; b) Aime, S.; Botta, M.; Geninatti Crich, S.; Giovenzana, G. B.; Jommi, G.; Pagliarin, R.; Sisti, M. Synthesis and NMR studies of three pyridine-containing triaza macrocyclic triacetate ligands and their complexes with lanthanide ions. Inorg. Chem. 1997, 36, 2992-3000; c) Siaugue, J.-M.; Segat-Dioury, F.; Favre-Réguillon, A.; Madic, C.; Foos, J.; Guy, A. An efficient synthesis of pyridine containing triaza-macrocyclic triacetate ligand and luminescence properties of its europium(III) complex. Tetrahedron Lett. 2000, 41, 7443-7446.

45. a) Aime, S.; Botta, M.; Frullano, L.; Geninatti Crich, S.; Giovenzana, G. B.; Pagliarin, R.; Palmisano, G.; Sisti, M. Contrast agents for magnetic resonance imaging: a novel route to enhanced relaxivities based on the interaction of a $\mathrm{Gd}(\mathrm{II})$ chelate with poly- $\beta$-cyclodextrins. Chem. Eur. J. 1999, 5, 1253-1260; b) Hovland, R.; Glogard, C.; Aasen, A. J.; Klaveness, J. Preparation and in vitro evaluation of a novel amphiphilic GdPCTA-[12] derivative; a micelar MRI contrast agent. Org. Biomol. Chem. 2003, 1, 644-647.

46. Aime, S.; Botta, M.; Frullano, L.; Geninatti Crich, S.; Giovenzana, G.; Pagliarin, R.; Palmisano, G.; Sirtori, F. R.; Sisti, M. [GdPCP2A $\left.\left(\mathrm{H}_{2} \mathrm{O}\right)_{2}\right]^{-}$: a paramagnetic contrast agent designed for improved applications in magnetic resonance imaging. J. Med. Chem. 2000, 43, 4017-4024.

47. Aime, S.; Gianolio, E.; Corpillo, D.; Cavallotti, C.; Palmisano, G.; Sisti, M.; Giovenzana, G. B.; Pagliarin, R. Designing novel contrast agents for magnetic resonance imaging. Synthesis and relaxometric characterization of three gadolinium(III) complexes based on functionalized pyridine-containing macrocyclic ligands. Helv. Chim. Acta 2003, 86, 615-632.

48. Zheng, Q.; Dai, H.; Merritt, M. E.; Malloy, C.; Pan, C. Y.; Li, W.-H. A new class of macrocyclic lanthanide complexes for cell labeling and magnetic resonance applications. J. Am. Chem. Soc. 2005, 127, 16178-16188.

49. a) Comblin, V.; Gilsoul, D.; Hermann, M.; Humblet, V.; Jacques, V.; Mesbahi, M.; Sauvage, C.; Desreux, J. F. Designing new MRI contrast agents: a coordination chemistry challenge. Coord. Chem. Rev. 1999, 185-186, 451-470; b) Paris, J.; Gameiro, C.; Humblet, V.; Mohapatra, P. K.; Jacques, V.; Desreux, J. F. Auto-assembling of ditopic macrocyclic lanthanide chelates with transition-metal ions. Rigid multimetallic high relaxivity contrast agents for magnetic resonance imaging. Inorg. Chem. 2006, 45, 5092-5102. 
50. a) Aime, S.; Geninatti Crich, S.; Gianolio, E.; Giovenzana, G. B.; Tei, L.; Terreno, E. High sensitivity lanthanide(III) based probes for MR-medical imaging. Coord. Chem. Rev. 2006, 250, 1562-1579; b) Lowe, M. P. Activated MR contrast agents. Curr. Pharm. Biotech. 2004, 5, 519528.

51. Woods, M.; Woessner, D. E.; Sherry, A. D. Paramagnetic lanthanide complexes as PARACEST agents for medical imaging. Chem. Soc. Rev. 2006, 35, 500-511.

52. García-Martín, M. L.; Herigault, G.; Remy, C.; Flarion, R.; Ballesteros, P.; Coles, J.; Cerdán S.; Ziegler, A. Mapping extracellular $\mathrm{pH}$ in rat brain gliomas in vivo by ${ }^{1} \mathrm{H}$ Magnetic Resonance Spectroscopy: comparison with maps of other metabolites. Cancer Res. 2001, 61, 6524-6531.

53. Pacheco-Torres, J.; Pérez-Mayoral, E.; Soriano, E.; López-Larrubia, P.; Ouari, O.; GonzálezCortés, A.; Cerdán, S.; Ballesteros, P. A convenient and efficient synthesis of the first nitroimidazolylsuccinic esters and their diacids. Synthesis 2006, 22, 3859-3864.

54. Soler-Padrós, J.; Pérez-Mayoral, E.; Domínguez, L.; López-Larrubia, P.; Soriano, E.; MarcoContelles, J. L.; Cerdán, S.; Ballesteros, P. A novel generation of $\mathrm{pH}$ indicators for proton magnetic resonance spectroscopic imaging. J. Med. Chem. 2007 (in press).

55. Provent, P.; Benito, M.; Hiba, B.; Farion, R.; López-Larrubia, P.; Ballesteros, P.; Rémy, C.; Segebarth, C.; Cerdán, S.; Coles, J. A.; García-Martín, M. L. Serial in vivo spectroscopic NMR imaging of lactate and extracellular $\mathrm{pH}$ in rat gliomas shows redistribution of protons away from sites of glycolysis. Cancer Res. 2007 (in press).

56. Bhujwala, Z.; Artemov, D.; Ballesteros, P.; Cerdán, S.; Gillies R.; Solaiyappan, M. Combined vascular and extracellular pH imaging of solid tumors. NMR Biomed. 2002, 15, 114-119.

Sample Availability: Contact the authors.

(c) 2007 by MDPI (http://www.mdpi.org). Reproduction is permitted for noncommercial purposes. 